Jari Ojala, Pirjo Vuorenpää, Anu Ojala, Mikko Hiljanen, Matti Rautiainen \& Jarmo Seppälä

\title{
KESKI-SUOMEN YRITYSTEN HISTORIATIETOISUUS
}

Kyselyn tulokset 


\section{JYU REPORTS 3}

Jari Ojala, Pirjo Vuorenpää, Anu Ojala, Mikko Hiljanen, Matti Rautiainen \& Jarmo Seppälä

\section{KESKI-SUOMEN YRITYSTEN HISTORIATIETOISUUS}

Kyselyn tulokset

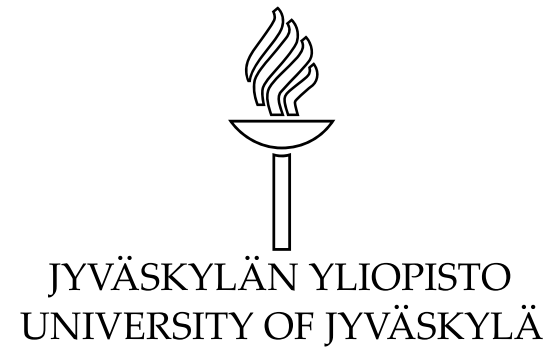


Copyright $@ 2021$, by University of Jyväskylä

This is a printout of the original online publication.

Permanent link to this publication: http://urn.fi/URN:ISBN: 978-951-39-8636-0

ISBN 978-951-39-8636-0 (PDF)

URN:ISBN:978-951-39-8636-0

ISSN 2737-0046

This work is licensed under a Creative Commons Attribution 4.0 International license (CC BY 4.0). 


\section{Sisällys}

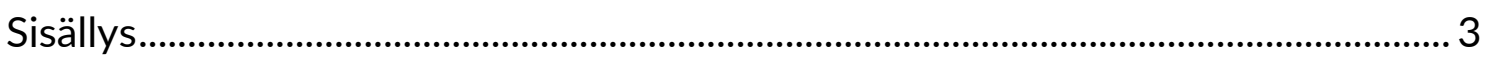

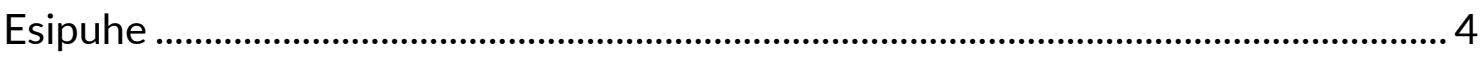

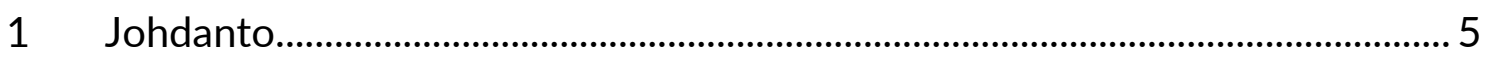

1.1. Organisaatioiden historiatietoisuus .......................................................... 5

1.2 Tämä tutkimus ...........................................................................................

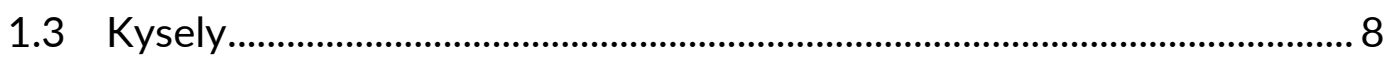

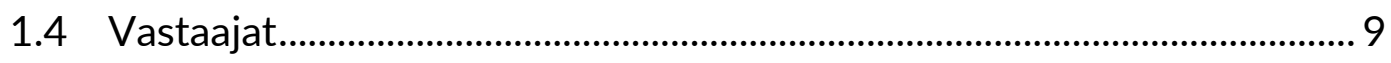

$2 \quad$ Kyselyn tulokset ..............................................................................................1

2.1 Vastaajien käsitys historiasta .....................................................................11

2.2 Yritys ja historia ........................................................................................

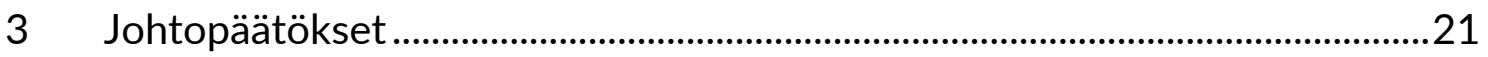

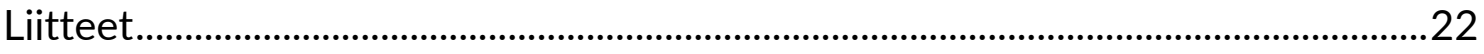

Liite 1 Vastanneiden yritysten ja vastaajien profiili .....................................22

Liite 2 Kyselylomake ..................................................................................... 24

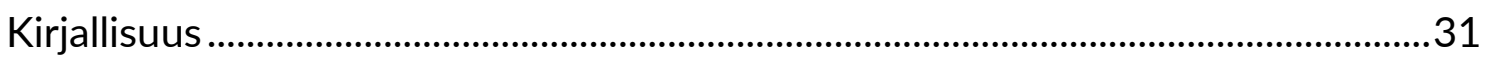

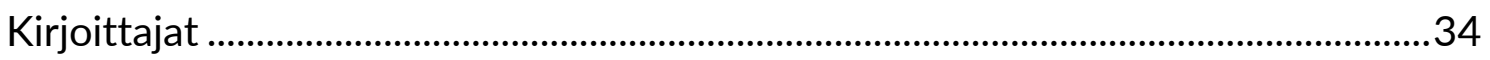




\section{ESIPUHE}

Tämä raportti on osa Jyväskylän yliopiston monitieteistä Menestystä menneisyydestä -tutkimushanketta, jossa selvitetään yritysten historiatietoisuutta. Raportin teko ei olisi ollut mahdollista ilman Keski-Suomen liiton ja Business Finlandin rahoitusta - kiitos molemmille tärkeästä tuesta tutkimushankkeelle. Kiitos myös Keski-Suomen Yrittäjille ja Keski-Suomen kauppakamarille, joiden verkostojen kautta kysely levisi keskisuomalaisyrityksille. Raportti on pohjana tutkimushankkeen seuraaville vaiheille, joissa sekä syvennytään tarkemmin yksittäisten yritysten historiatietoisuuteen että laajennetaan analyysiä valtakunnalliselle tasolle.

Jyväskylässä toukokuussa 2021

Tekijät 


\section{JOHDANTO}

\subsection{Organisaatioiden historiatietoisuus}

Suomalainen talouselämä on kiinnostunut historiastaan. Muuten ei voi selittää sitä, että vuosien saatossa suomalaisyrityksistä on kirjoitettu noin 3500 yrityshistoriaa, joista pelkästään viimeisen kymmenen vuoden aikana viitisensataa. Eikä kirjoja ole tehty vain suurista pörssiyhtiöistä; mukana on niiden lisäksi niin pieniä kuin keskisuuriakin firmoja eri puolilta Suomea.

Yrityshistoriat ovat yksi näkyvä esimerkki siitä, kuinka yritykset ovat osa historiaa ja aivan olennainen osa yhden jos toisenkin paikkakunnan menneisyyttä. Joillekin yrityksille historia näkyy vanhojen rakennusten ja tuotantolaitosten ylläpidossa tai vaikkapa koneiden, laitteiden ja tuotteiden museoinnissa. Toisille historia on yritysten merkkihenkilöiden maalauksia toimitilojen seinillä, joillekin vanhoja valokuvia tai muisteluita ja tarinoita menneestä. Historian tallentamista voi olla myös yritystä koskevien lehtileikkeiden kerääminen tai yrityksen asiakirjojen arkistoiminen.

Yrityshistorioita ja muuta historian käyttöä voidaan pitää merkkinä yritysten historiatietoisuudesta. Viime vuosina onkin ilmestynyt runsaasti tutkimuksia yritysten historiatietoisuudesta ja siitä, miten yritykset hyödyntävät joko oman yrityksensä tai paikkakuntansa historiaa liiketoiminnassaan. Historiaa on hyödynnetty muun muassa markkinoinnissa ja brändin rakentamisessa. Esimerkiksi Ruotsin ja Saksan perheyrityksiä koskevassa tutkimuksessa selvitettiin miksi ja miten perheen ja yrityksen historia ilmenevät perheyritysten identiteetissä tai brändissä (Blombäck \& Brunninge, 2016). Italiassa on tutkittu Modenan alueella syntynyttä moottoriurheilun keskittymää, Motor Valley Clusteria. Siellä alueen identiteetti ja moottoriurheiluteollisuuden historiallinen perimä 1800-luvulta alkaen ovat mahdollistaneet nykyaikaisen klusterin, jossa suurin osa yrityksistä eri toimitaloilla ovat tiukasti sidoksissa keskenään hyödyttäen ja vahvistaen alueen kilpailukykyä (Alberti \& Giusti, 2012). 
Hans-Georg Gadamer ja Hans Fantel (1975) ovat todenneet, että historiatietoisuus on "täyttä ymmärrystä siitä, että historiallisuus liittyy kaikkeen nykyiseen". Heidän mukaansa historiatietoisuus on modernin ajan ilmiö ja sen henkinen merkitys on valtava koko modernin yhteiskunnan muotoutumisen kannalta; jopa suurempi kuin luonnontieteiden saavutukset. Gadamerin ja Fantelin mukaan historiatietoisuus tarkoittaa ennen muuta ymmärrystä historian suhteellisuudesta ja monitulkintaisuudesta. Suhteellisuus ja tulkinnallisuus ovat edellytys historian ja aikaisempien käsitysten kriittiseen uudelleenarviointiin, mikä puolestaan on mahdollistanut muutoksen ja innovoinnin, kuten Joel Mokyr (2016) on korostanut selittäessään modernin talouskasvun syntyä. Mallia voi soveltaa myös organisaatiotasolla, jossa historiatietoisuus on edellytys kriittiseen oman (ja muiden) toiminnan tulkitsemiseen, mikä on keskeinen edellytys yritysten tulevaisuuden suunnittelulle ja selviytymiselle muutostilanteissa (esim. Suddaby \& Foster, 2017). Historiatietoisuuden käsitettä on käytetty ja kehitetty erityisesti historian oppimisen ja opettamisen tutkimuksessa (erityisesti Seixas, 2004; Rüsen, 2004; Lee, 2004; Suomessa ks. etenkin Torsti, 2012; Ahonen, 1998; van den Berg, 2007 Pihlainen 2011; Veijola 2016; Veijola \& Mikkonen 2016) ja viime aikoina myös liiketoimintahistoriassa (Suddaby, 2016; Suddaby \& Foster, 2017).

Yrityksen historiatietoisuus ilmenee yhdistelmänä jokapäiväisen toiminnan käytäntöjä, organisaation kollektiivista muistia, identiteettiä ja jaettuja arvoja sekä historiakuvaa, jolla yritys näyttäytyy ulospäin (Kuvio 1). Konkreettisesti historiatietoisuus voi näkyä yrityksen historian tallentamisessa esimerkiksi arkistoon, museokokoelmiin, taideteoksiin tai rakennuksiin. Yritykset voivat hyödyntää historiaansa myös markkinoinnissa, brändin rakentamisessa, tarinallisuudessa sekä esimerkiksi strategisessa johtamisessa (esim. Goulding, 2000; Penaloza, 2000; Rindell \& al., 2015). Anne Rindell \& al. (2015) onkin todennut osuvasti, että aineellisen kulttuuriperinnön (cultural heritage) rinnalla tulisi puhua myös aineettomasta brändiperimästä (brand heritage). 


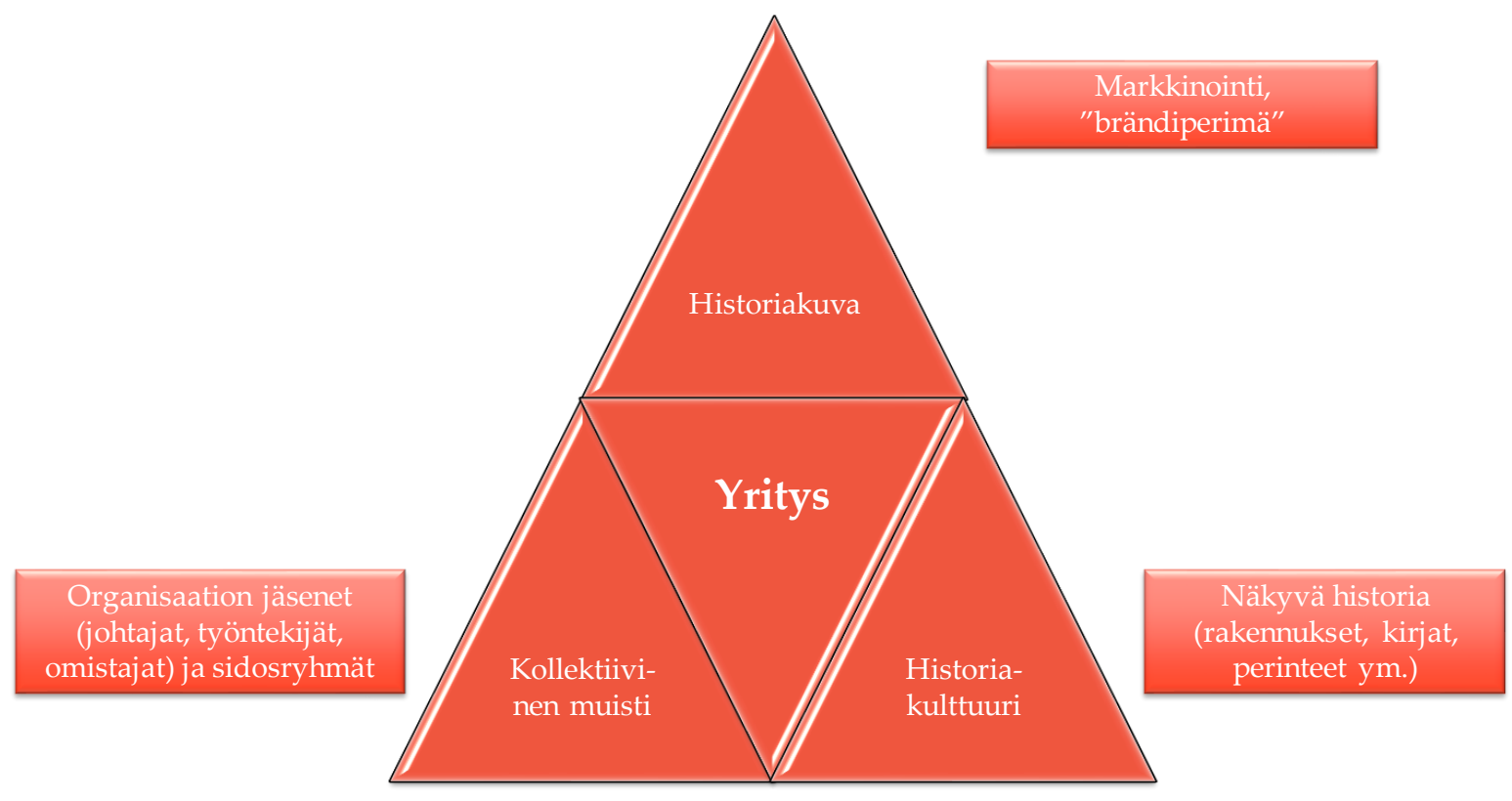

Kuvio 1 Historiatietoisuus ja yritys

Viimeaikaisessa organisaatiotutkimuksessa on käsitteellistetty historian merkitystä organisaatioille; jotkut tutkijat puhuvat suorastaan "historiallisestä käänteestä" organisaatioiden tutkimuksessa (Kipping \& Üsdiken, 2014; Clark \& Rowlinson 2004; Mills et al. 2016; Kieser 1994; Üsdiken \& Kieser, 2004; Brunninge 2009). Käänteen myötä historia on otettu olennaiseksi osaksi mukaan esimerkiksi strategisen johtamisen tutkimuksessa (Vaara \& Lamberg, 2016). Historiatietoisuus voi tarjota yrityksille keinon tulkita ja käyttää omaa menneisyyttään ja sen merkityksiä autenttisuuden, identiteetin, kulttuurin ja legitimiteetin rakentamisessa (Foster et al., 2017). Suddaby ja Foster (2017) korostavat "retorista historian käyttöä" (rhetorical history); historian määrätietoista hyväksikäyttöä organisaation toiminnassa. Siksi on mielenkiintoista tutkia, koetaanko organisaatioissa oma historia toimintaa määrittävänä pysyvänä ominaisuutena, joko vahvuutena (Barney, 1991; Teece, Pisano \& Shuen, 1997) tai toimintaa jäykistävänä polkuriippuvuutena (Arthur, 1989; David, 1985). Voisiko historia olla organisaatioille jopa muokattava strateginen resurssi (Brunninge, 2009; Suddaby, Foster \& Quinn Trank, 2010; Maclean et al., 2018)?

\subsection{Tämä tutkimus}

Jyväskylän yliopiston historian ja etnologian laitoksella syksyllä 2019 käynnistyneessä Menestystä Menneisyydestä -tutkimushankkeessa analysoidaan yritysten historiatietoisuutta ja sen käyttöä yrityksen liiketoiminnassa, kuten johtamisessa, markkinoinnissa 
ja brändin rakentamisessa (www.jyu.fi/firmstory). Tutkimuksessa yhdistetään liiketoimintahistorian ja organisaatiotutkimuksen (esim. Wadhwani \& al., 2018) näkökulmia. Ensimmäinen pilottitutkimus suomalaisten perheyritysten historiatietoisuudesta tehtiin yhteistyössä Perheyritysten Liiton kanssa (Hiljanen \& al., 2021).

Keskisuomalaisyrityksille keväällä 2021 tehdyssä tutkimuksessa tavoitteena oli selvittää yritysten historiatietoisuutta ja auttaa niitä tiedostamaan historian hyödyntämisen mahdollisuudet liiketoiminnan kehittämisessä. Ensimmäisessä vaiheessa toteutettiin kysely, jonka tulokset raportoidaan tässä selvityksessä. Seuraavassa vaiheessa haastatellaan kyselyn avulla vapaaehtoiseksi ilmoittautuneiden yritysten edustajia sekä toteutetaan valmennuksia yrityksille. Näiden avulla yritykset saavat tietoa ja tarpeitansa vastaavia uusia työkaluja liiketoiminnan kehittämiseen, kuten johtamiseen, markkinointiin ja brändin rakentamiseen ja samalla tutkijat saavat arvokasta aineistoa.

Kyselytutkimuksen rahoittaja on Keski-Suomen Liitto ja Jyväskylän yliopisto. Yhteistyökumppaneita ovat Keski-Suomen Yrittäjät ja Keski-Suomen kauppakamari, joiden verkostojen kautta lähestyimme alueen yrityksiä. Hanke on saanut tukea myös Business Finlandilta.

\subsection{Kysely}

Vuoden 2018 alussa Keski-Suomessa oli Tilastokeskuksen mukaan 16285 yritystä (tilastokeskus). Kyselylinkki jaettiin Keski-Suomen Kauppakamarin (650 jäsentä) ja KeskiSuomen Yrittäjien (3 500 jäsentä) jäsenyritysten edustajille - osin kyseessä ovat samat yritykset. Potentiaalisia vastaajia oli siis noin 4000 , mutta vastanneiden määrä jäi pieneksi (54 vastausta). Nettikyselyissä vastausprosentit jäävät yleensä alhaisiksi (Berndtson \& Lounasmaa, 2004). Myös samanaikaiset muut kyselyt (esim. kauppakamarin koronakysely) saattoivat vähentää vastausintoa. Yrittäjille tieto kyselystä lähetettiin linkkinä yleisen tiedotteen muun sisällön ohessa; on mahdollista, että osa viestin saajista ei yksinkertaisesti sitä huomannut. Todennäköisesti kauppakamarin lähettämät henkilökohtaiset sähköpostit tavoittivat vastaajat paremmin. Kauppakamarin osalta vastausprosentti oli 8,3 ja yrittäjien osalta 1,5\%.

Kyselyn tuloksia arvioitaessa on siis huomioitava ensinnäkin pieni vastaajien lukumäärä ja toiseksi se, että todennäköisesti tulokset ovat ainakin jossain määrin vinoja: kyselyyn vastasivat erityisesti ne, joille kyselyn sisältö oli kiinnostava. Toisin sanoen: vastaajille historian käyttö on joko tuttua tai muuten kiinnostavaa. Kolmanneksi kyselyn tuloksiin vaikuttaa luonnollisesti kohdealue (Keski-Suomi). Vastausten jakauman perusteella mukana oli kuitenkin hyvin laajalla skaalalla erikokoisia, eri-ikäisiä ja eri toimialoilla operoivia yrityksiä. Otos on kuitenkin niin pieni, ettei tilastollisesti luotettavia ristiintaulukointeja näiden muuttujien avulla voi tehdä. 
Kyselyssä kartoitettiin laajasti yritysten - tai tarkemmin yritysten edustajien käsityksiä historiasta ja sen mahdollisesta hyödyntämisestä yritystoiminnassa (kyselomake liitteessä 2). Osa kysymyksistä oli mukailtu Pilvi Torstin (2012) johtamasta suomalaisten historiatietoisuutta kartoittaneesta hankkeesta. Näin kyselyn tulokset ovat vertailukelpoisia myös ao. tutkimuksen kanssa. Torstin kyselyyn vastasi kaikkiaan 1208 suomalaista, näistä 56 Keski-Suomesta (4,3 \%) (Torsti, Knuuttila \& Hämäläinen, 2012). Molempien kyselyiden vastaajamäärä on siis Keski-Suomen osalta lähes identtinen.

Keskisuomalaisyrityksille tehty kysely on luonteeltaan pilottitutkimus: sen antamia oppeja noudattaen on tavoitteena tehdä koko Suomen yrityskenttää koskeva kysely syksyllä 2021. Erityisen tärkeää on myös se, että kyselyn avulla löydettiin lukuisia yrityksiä, jotka haluavat jatkaa tutkimuksen tekoa syvähaastatteluilla.

Kysely toteutettiin Webprobol -verkkokyselynä. Vastausaika oli helmi-maaliskuu 2021. Yrityksiä informoitiin Keski-Suomen yrittäjien ja Keski-Suomen kauppakamarin välityksellä. Näiden lisäksi toteutettiin somekampanja ja kontaktoitiin yrityksiä myös suoraan.

\subsection{Vastaajat}

Kyselyyn vastasi kaikkiaan 54 keskisuomalaisyritystä. Yritysten ja vastaajien tarkemmat tiedot on koottu liitteeseen (Liitekuviot 1-8). Vastanneet yritykset jakautuivat tasaisesti iän, koon ja toimialan mukaan. Kymmenen vuotta tai nuoremmat yritykset muodostivat vaajaan viidenneksen, 10-50-vuotiaat yritykset reilut puolet ja tätä vanhemmat runsaan neljäsosan vastanneista. Runsaalla kolmanneksella yrityksistä oli alle miljoonan euron liikevaihto, kolmasosa sijoittui kokoluokkaan 1-9 miljoonaa euroa ja kolmasosa oli tätä suurempia. Sama jakauma näkyy myös henkilöstön määrässä: vajaa kolmannes oli 1-5 henkilöä työllistäviä yrityksiä, noin 40 prosenttia työllistää 5-49 henkilöä ja kolmasosa vastaajista työllistää yli 50 henkeä. Suurin osa vastanneista yrityksistä oli yritysmuodoltaan osakeyhtiöitä (81 \%), lisäksi joukossa oli muutama kommandiittiyhtiö, toiminimi ja osuuskunta. Tasan puolet $(n=27)$ vastaajista katsoi yrityksensä olevan perheyritys. Toimialoittain tarkastellen teollisuusyrityksiä oli 30 prosenttia vastanneista, tätä seuraavat suurimmat yksittäiset toimialaluokat olivat "muu palvelutoiminta " (13 \%) sekä tukku- ja vähittäiskauppa (7 \%). Toimialoista etenkin rakentaminen, tukku- ja vähittäiskauppa sekä kiinteistöala ovat selvästi aliedustettuina, kun vastaajien lukumääriä vertaa tilastokeskuksen lukuihin Keski-Suomen yrityskannasta. Kolmannes vastaajista katsoi, että yrityksen päätoimialue on kansallinen, viidennes näki markkinaalueen alueellisena ja neljäsosa kansainvälisenä. Paikallinen markkina-alue on yhdeksällä ja globaali 13 prosentilla vastaajista. 
Vastaajista 61 prosenttia oli yrityksen omistajia. Suurimmalla osalla heistä oli yhä aktiivinen rooli yrityksen johdossa. Palkkasuhteessa yritykseen oli 37 prosenttia vastaajista; heistä kaikki oli joko johtavassa asemassa tai asiantuntijatehtävässä yrityksessä. Vastaajista suurin osa oli yli 55-vuotiaita (54\%). Vastaajien joukossa ei ollut alle 36-vuotiaita. 


\section{KYSELYN TULOKSET}

\subsection{Vastaajien käsitys historiasta}

Kyselyn ensimmäisessä kysymysryhmässä (Kuviot 2-4) selvitettiin vastaajien henkilökohtaista kiinnostusta historiaan. Kysymykset noudattavat pääosiltaan Pilvi Torstin (2012) historiatietoisuushankkeen kysymyspatteristoa. Torstin tutkimuksesta poiketen yritysten historiatietoisuushankkeessa nostettiin esiin yrityksiä suoraan koskevia teemoja, kuten taloutta ja yritysten historiaa. Torstin tutkimuksen patteriston kysymyksiä myös selkeytettiin ja yksinkertaistettiin. Kyselylomake on liitteessä 2.

Kyselyn perusteella keskisuomalaisyritysten edustajat ovat kiinnostuneita historiasta (Kuvio 2). Vastausten perusteella historiaa myös halutaan käyttää aktiivisesti: historian avulla opitaan virheistä ja onnistumisesta; sen avulla saadaan taustaa ja selityksiä nykyongelmille, ja historian kautta saa tietoa, joka auttaa ymmärtämään talouden kehityskulkuja ja ilmiöitä. Kaikki vastaajat katsoivat, että historian on osa kaikille kuuluvaa yleissivistystä. 

ilmiöitä

Yleissivistystä: perustiedot historiasta kuuluvat jokaisen yleissivistykseen

Oppiainetta koulussa, johon liittyviä tietoja tai taitoja en ole tarvinnut kouluaikojeni jälkeen

$$
\begin{array}{lll}
\square \text { 5=täysin samaa mieltä } & \square=\text { =osin samaa mieltä } & \square=\text { ei samaa, ei erimieltä } \\
\square=\text { osin eri mieltä } & \square \text { l=täysin eri mieltä } & \square=\text { en osaa/halua sanoa }
\end{array}
$$

Kuvio 2 Mitä historia merkitsee sinulle henkilökohtaisesti? (Prosenttia vastauksista, $\mathrm{N}=54)$

Vastaajien ikä tai asema yrityksessä eivät vaikuta merkittävästi tuloksiin (Taulukko 1). Tulosten perusteella alle 56-vuotiaat ovat hieman valmiimpia ottamaan oppia historiasta kuin yli 55-vuotiaat. Vastaavasti omistajat vaikuttaisivat olevan aavistuksen valmiimpia hyödyntämään historiaa. Otos on kuitenkin niin pieni, ettei tuloksia voi yleistää.

Taulukko 1 Vastaajien tausta vaikutus historiakiinnostuksen eri alueisiin

\begin{tabular}{|c|c|c|c|c|c|}
\hline & Kaikki & $\begin{array}{l}\text { Alle 56- } \\
\text { vuotiaat }\end{array}$ & $\begin{array}{l}\text { Yli 55- } \\
\text { vuotiaat }\end{array}$ & $\begin{array}{l}\text { Omis } \\
\text {-tajat }\end{array}$ & $\begin{array}{l}\text { Palkka- } \\
\text { suh- } \\
\text { teessa }\end{array}$ \\
\hline Kiehtovia asioita, jotka kiinnostavat minua. & 4,6 & 4,6 & 4,6 & 4,5 & 4,5 \\
\hline Yleissivistystä & 4,6 & 4,7 & 4,6 & 4,7 & 4,6 \\
\hline ...auttaa minua ymmärtämään yhteiskuntaa ... & 4,4 & 4,6 & 4,3 & 4,4 & 4,5 \\
\hline $\begin{array}{l}\text { mille } \\
\text { Tilaisuutta oppia muiden virheistä ja onnistumi- }\end{array}$ & 4,3 & 4,6 & 4,1 & 4,3 & 4,4 \\
\hline sista & 4,3 & 4,5 & 4,1 & 4,4 & 4,2 \\
\hline $\begin{array}{l}\text { Menneitä ja kuolleita asioita... } \\
\text {..auttaa minua ymmärtämään talouden kehitys- }\end{array}$ & 1,3 & 1,3 & 1,3 & 1,5 & 1,3 \\
\hline kulkuja.. & 4,3 & 4,5 & 4,2 & 4,3 & 4,3 \\
\hline Oppiainetta koulussa.... & 1,7 & 1,7 & 1,8 & 1,7 & 1,8 \\
\hline $\mathrm{N}$ & 54 & 25 & 29 & 33 & 24 \\
\hline
\end{tabular}

(Keskiarvot vastauksista, 1=täysin eri mieltä, 5 = täysin samaa mieltä) 


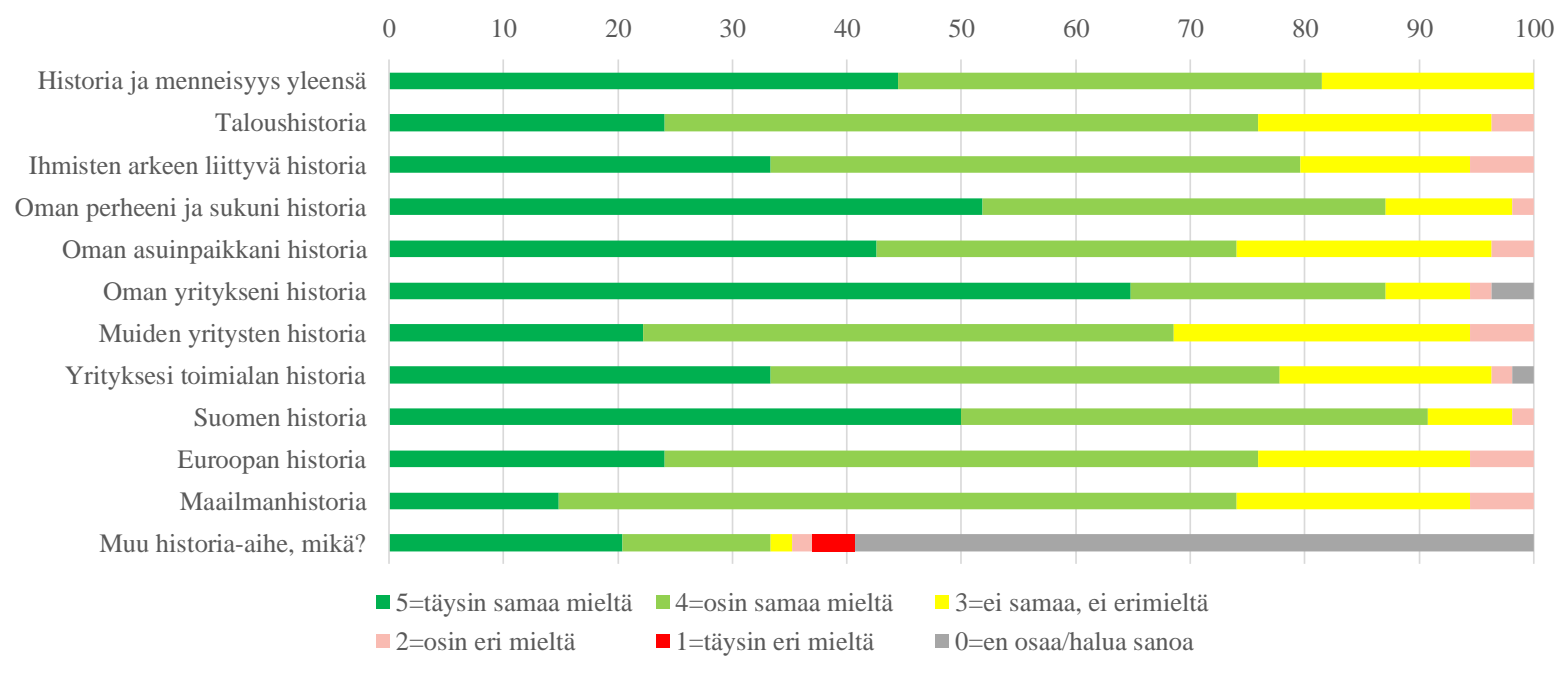

Kuvio 3 Kuinka kiinnostavana pidät seuraavia asioita? (Prosenttia vastauksista, $N=54$ )

Vastaajat olivat kiinnostuneita monista historian osa-alueista, kuten Kuviosta 3 käy ilmi. Erityisen kiinnostuneita vastaajat olivat Suomen historiasta, oman yrityksen historiasta sekä oman perheen ja suvun historiasta. Tuloksia voisi tulkita niin, että läheinen ja henkilökohtainen historia kiinnostaa keskisuomalaisyritysten edustajia. Sen sijaan muiden yritysten historia, Euroopan historia tai maailmanhistoria kiinnosti vastaajia selvästi vähemmän. Muina historiankiinnostuksen kohteina avovastauksissa mainittiin muun muassa demokratian ja tasa-arvon historia, tekniikan historia, sukututkimus ja historian sekä tulevaisuuden suhteen tulkinnan pohtiminen.

Historian fiktiivinen käyttö oli useimmille vastaajista vähintään kuukausittaista, kun taas historian aktiivinen keräily, museokäynnit tai historia-aiheiset pelit eivät olleet kovin yleistä historian käyttöä vastaajille (Kuvio 4). Koronavuoden vuoksi historia-aiheisilla luennoilla tai esitelmätilaisuuksissa ei oltu juurikaan käyty. Noin puolet vastaajista perehtyi vähintään kuukausittain oman yrityksensä historiaan, mutta hieman harvemmin muiden yritysten tai oman toimialan historiaan. Muun historiatiedon etsiminen kirjoista ja internetistä oli verrattain yleistä. 


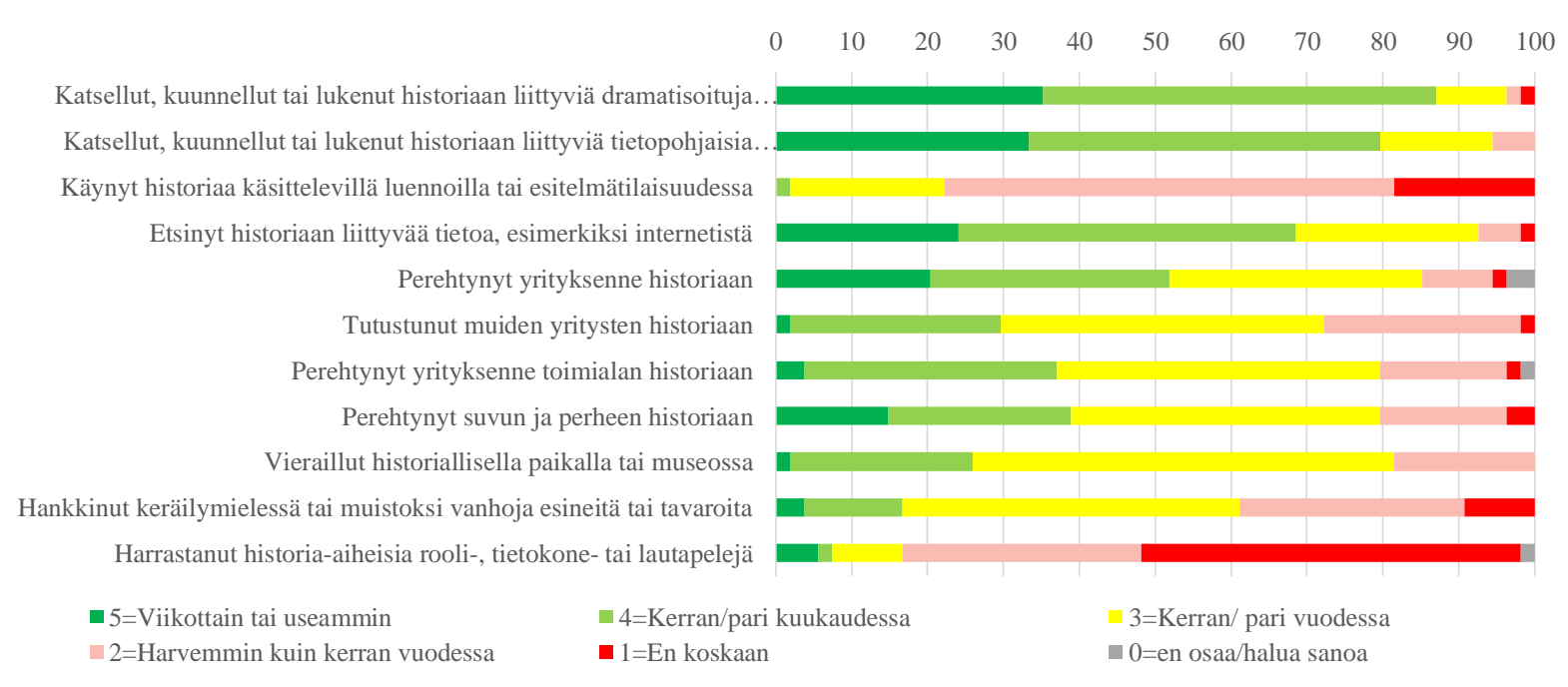

Kuvio 4 Historian käyttö: kuinka usein olet... (Prosenttia vastauksista, N=54)

Historian käyttöön (Kuvio 4) liittyvät tulokset ovat kiinnostavia: vaikuttaisi siltä, ettei yrityksissä olla erityisen kiinnostuneita benchmarkkaamaan muiden yritysten tai oman toimialan historiaa. Lähempi tarkastelu vastaajittain osoittaa, että johtavassa asemassa olevat ovat perehtyneet selvästi enemmän paitsi oman yrityksen historiaan myös muiden yritysten ja oman toimialan historiaan. Vastausten määrä on kuitenkin niin pieni, että tarvitaan lisätutkimusta asian vahvistamiseksi.

\subsection{Yritys ja historia}

Tutkimuksen toisessa kysymysryhmässä selvitettiin historian käyttöä vastaajien yrityksessä. Tähän kyselyn osaan ei ollut käytössä tutkimuksellista esikuvaa. Kysymyspatteriston rakentamisessa hyödynnettiin suomalaisille perheyrityksille tehtyä pilottitutkimusta, jossa haastateltiin parikymmentä perheyritysten edustajaa (Hiljanen \& al., 2021). Tuo tutkimus tehtiin yhteistyössä Suomen Perheyritysten liiton kanssa.

Ensimmäisessä yritysten historiaan liittyvässä osiossa kysyttiin yritysten materiaalisen kulttuuriperinnön tallentamista (Kuviot 5 ja 6). Kuvion 5 perusteella puolella vastanneista yrityksistä oli paljon tai erittäin paljon erilaisia kirjallisia aineistoja (arkistot, viestintäaineisto, lehtiartikkelit, tallennetut muistelmat) - aineisto on sekä paperisessa että sähköisessä muodossa. Myös valokuvia, videoita ja taideteoksia oli ainakin jonkin verran suurimmalla osasta yrityksiä. Sen sijaan museaalista aineistoa kuten rakennuksia, tuotteita tai koneita oli selvästi harvemmalla. Avovastauksissa mainittiin lisäksi muun muassa yritysten vanhat kalusteet, työkalut, vuosikertomukset, erilaiset käyttöohjeet sekä tuotteiden prototyypit. 


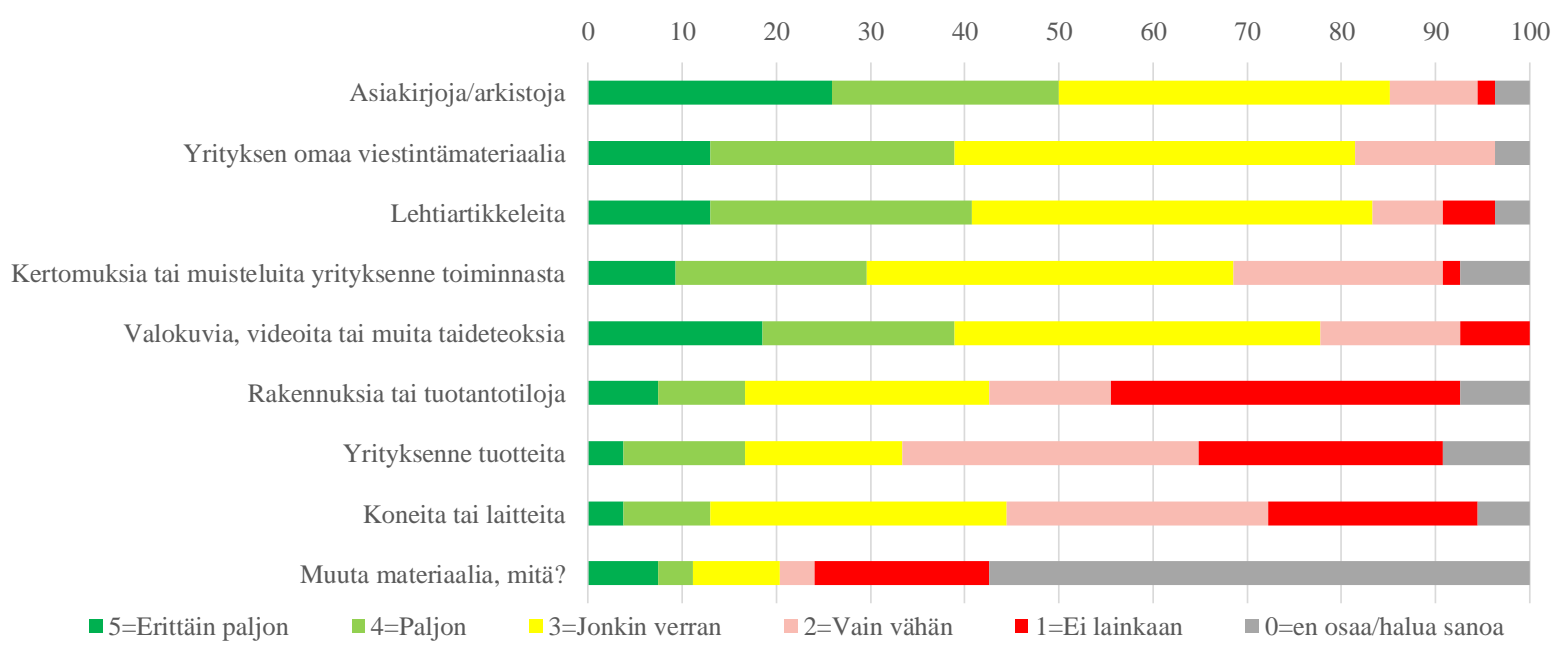

Kuvio 5 Onko yrityksessänne tallennettu tai säilytättekö yrityksenne historiaan liittyviä... (\% vastauksista, $\mathrm{N}=54$ )

Tuloksia voi tarkastella tarkemmin yritysten iän, koon ja toimialan suhteessa (Taulukko 2). Ei ole yllättävää, että kaikkein iäkkäimmiltä yrityksiltä on säilynyt enemmän asiakirjoja ja muuta aineistoa. Tämän ristiintaulukoinnin perusteella myös suuremmilla yrityksillä on luonnollisestikin enemmän aineellista kulttuuriperintöä kuten asiakirjoja, viestintämateriaalia, lehtiaineistoa, valokuvia ja tuotantotiloja. Suuremmat yritykset ovat myös keränneet aktiivisemmin kertomuksia ja muisteluita yrityksen toiminnasta. Yrityksen koko korreloi ainakin jossain määrin sen kanssa, onko kyseessä perheyritys vai ei: perheyrityksiä on suhteessa enemmän pienemmissä yrityksissä. Tämän vuoksi perheyrityksistä on vähemmän tallessa aineellista ja aineetonta kulttuuriperintöä, joskin poikkeuksiakin on: perheyrityksistä näyttäisi olevan enemmän tallessa muistitietoa ja lehtileikkeitä sekä rakennuksia ja tuotantotiloja.

Taulukko 2 Yritysten aineeton ja aineellinen kulttuuriperintö eri ikäisillä ja erikokoisilla yrityksillä (keskiarvot, $1=$ =i lainkaan, $5=$ =erittäin paljon)

\begin{tabular}{|c|c|c|c|c|c|c|}
\hline & Kaikki & $\begin{array}{l}\text { Ikä } 25 \text { v/ } \\
\text { nuorempi }\end{array}$ & $\begin{array}{l}\text { Ikä } \\
26-50 \\
\text { vuotta }\end{array}$ & $\begin{array}{l}\text { Ikä } 51 \text { vuotta } \\
\text { tai vanhempi }\end{array}$ & $\begin{array}{l}\text { Liikevaihto } \\
\text { alle } 5 \text { me }\end{array}$ & $\begin{array}{l}\text { Liikevaihto } 5 \\
\text { me tai enem- } \\
\text { män }\end{array}$ \\
\hline Asiakirjoja/arkistoja & 3,5 & 3,5 & 3,1 & 4,0 & 3,4 & 3,8 \\
\hline Viestintämateriaalia & 3,3 & 3,2 & 2,9 & 3,7 & 3,2 & 3,5 \\
\hline Lehtiartikkeleita & 3,2 & 3,1 & 3,1 & 3,7 & 3,2 & 3,6 \\
\hline Muistitietoa & 2,9 & 2,6 & 2,7 & 3,6 & 2,9 & 3,2 \\
\hline Valokuvia, taidetta... & 3,3 & 3,2 & 2,8 & 3,9 & 3,2 & 3,5 \\
\hline Rakennuksia... & 2,1 & 1,8 & 2,1 & 2,8 & 1,7 & 2,9 \\
\hline Tuotteita & 2,1 & 1,8 & 2,1 & 2,6 & 2,0 & 2,3 \\
\hline Koneita tai laitteita & 2,3 & 1,9 & 1,9 & 3,3 & 2,1 & 2,7 \\
\hline $\mathrm{N}$ & 54 & 24 & 15 & 15 & 31 & 21 \\
\hline
\end{tabular}


Runsaasta kolmanneksesta (35 \%) vastanneista yrityksistä on kirjoitettu yrityshistoria. Kaikkiaan yrityshistoria on kirjoitettu 19:stä kyselyyn vastanneesta yrityksestä: puolet näistä on perheyrityksiä ja valtaosa on suurempia yrityksiä (liikevaihto viisi miljoonaa tai enemmän). Kuvion 6 mukaan runsas viidennes vastaajista on kiinnostunut yrityshistorian kirjoittamisesta - jos mukaan otetaan myös "jonkin verran" kiinnostuneet, nousee osuus 60 prosenttiin. Sen sijaan yrityksissä oltaisiin selvästi kiinnostuneempia muistitiedon ja yritysten esineistön tallentamisesta. Rakennusten museointia ei nähty erityisen ajankohtaisena asiana.

yritykseenne liittyvien asiakirjojen tai dokumenttien arkistoinnista

yritykseen liittyvän muistitiedon tallentamisesta

yritykseennne liittyvän esineistön tallentamisesta

yritykseenne historiaan liittyvien rakennusten kunnossapidosta tai museoinnista

yrityshistorian kirjoittamisesta
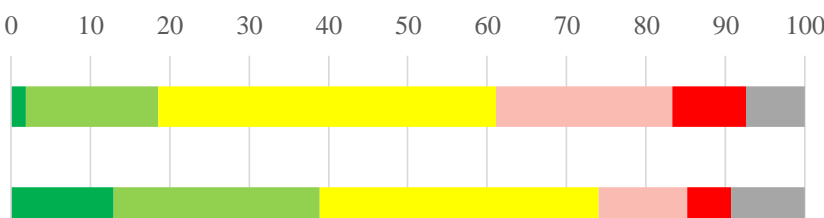

5=Erittäin paljon kiinnostunut

4=Kiinnostunut

- 1=Ei lainkaan kiinnostunut

3=Jonkin verran kiinnostunut

2=Vain vähän kiinnostunut

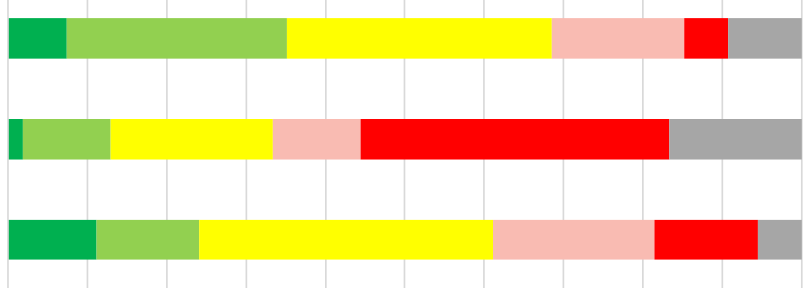

- $0=$ en osaa/halua sanoa

Kuvio 6 Kuinka kiinnostuneita olisitte... (\% vastauksista, $N=54$ )

Seuraavassa kysymysryhmässä mentiin syvemmälle historian päivittäisen käytön pohdintaan yrityksissä (Kuviot 7 ja 8). Suurin osa vastaajista näki oman yrityksen historian sekä oman henkilökohtaisen historian tärkeänä yrityksen päivittäisessä toiminnassa (Kuvio 7). Sen sijaan sidosryhmien, ympäröivän yhteisön tai yhteiskunnan historiaa ei nähty niinkään tärkeänä. Avovastauksissa korostettiin erityisesti asiakkaita ja henkilöstöä myös historian näkökulmasta. Samoin nostettiin esiin muun muassa yhteiskunnan kehitys ja rakennemuutos, paikkakunnan kehitys sekä kaavoituksessa ja yritystuissa tapahtuneet muutokset. 


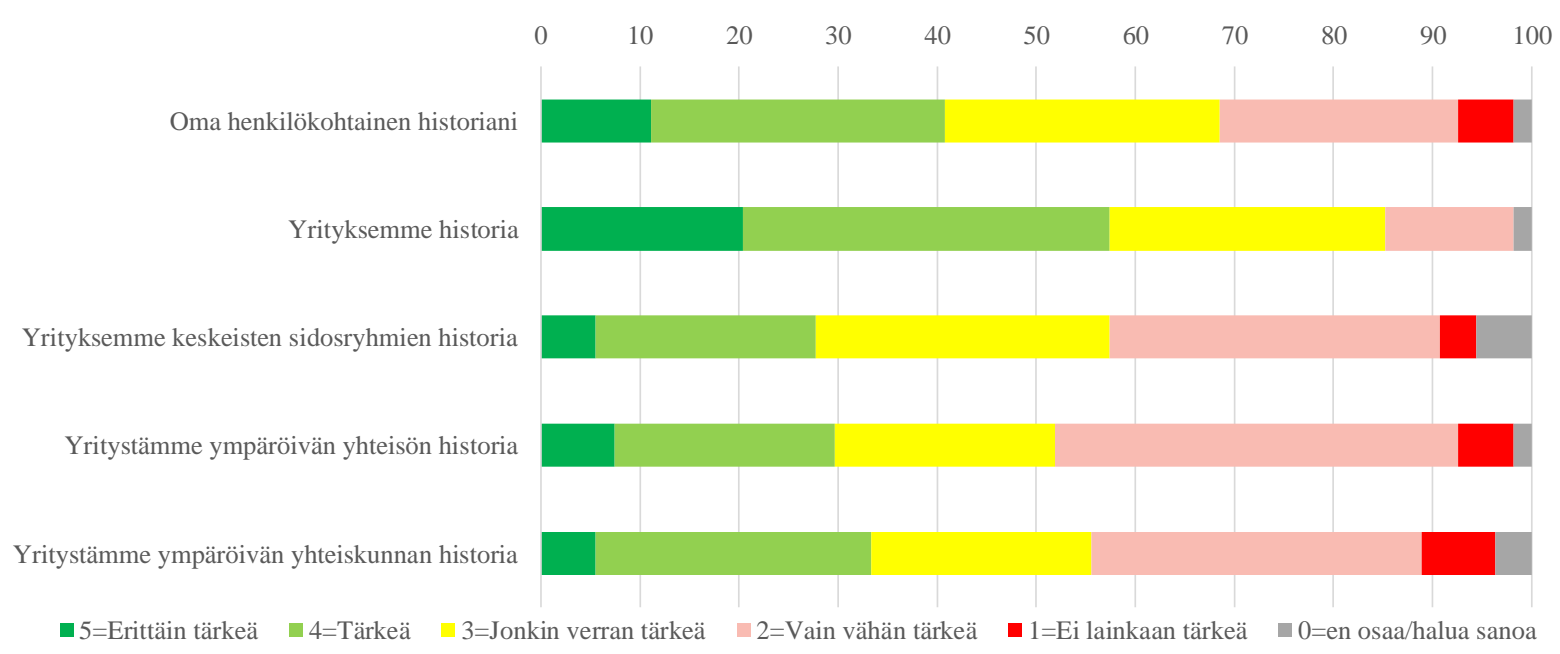

Kuvio 7 Kuinka tärkeä rooli seuraavilla on yrityksenne jokapäiväisessä toiminnassa ja tulevaisuuden suunnittelussa (\% vastauksista, $\mathrm{N}=54$ )

Kuvion 8 perusteella historia nähdään positiivisena tekijänä yrityksen toiminnassa ja historiatietoa hyödynnetään aktiivisesti yritysten toiminnassa sekä tulevaisuuden suunnittelussa. Käytännön toiminnassa painottuu kuitenkin ennen muuta historiallisen taloustiedon hyödyntäminen. Avovastauksissa yritykset tarkensivat sitä, miten historiaa hyödynnetään. Avovastauksissa nousi muun muassa paikallishistorian hyödyntäminen, "hiljaisen" historiatiedon käyttö (esim. henkilöstö), aiempien skenaarioiden, kehityssuunnitelmien ja tuotekehityksen aineistojen hyödyntäminen; sidosryhmien ja asiakaskontaktien tieto sekä myös laajamittainen tutkimustiedon hyödyntäminen (yhteiskuntatieteet ja historiantutkimus).

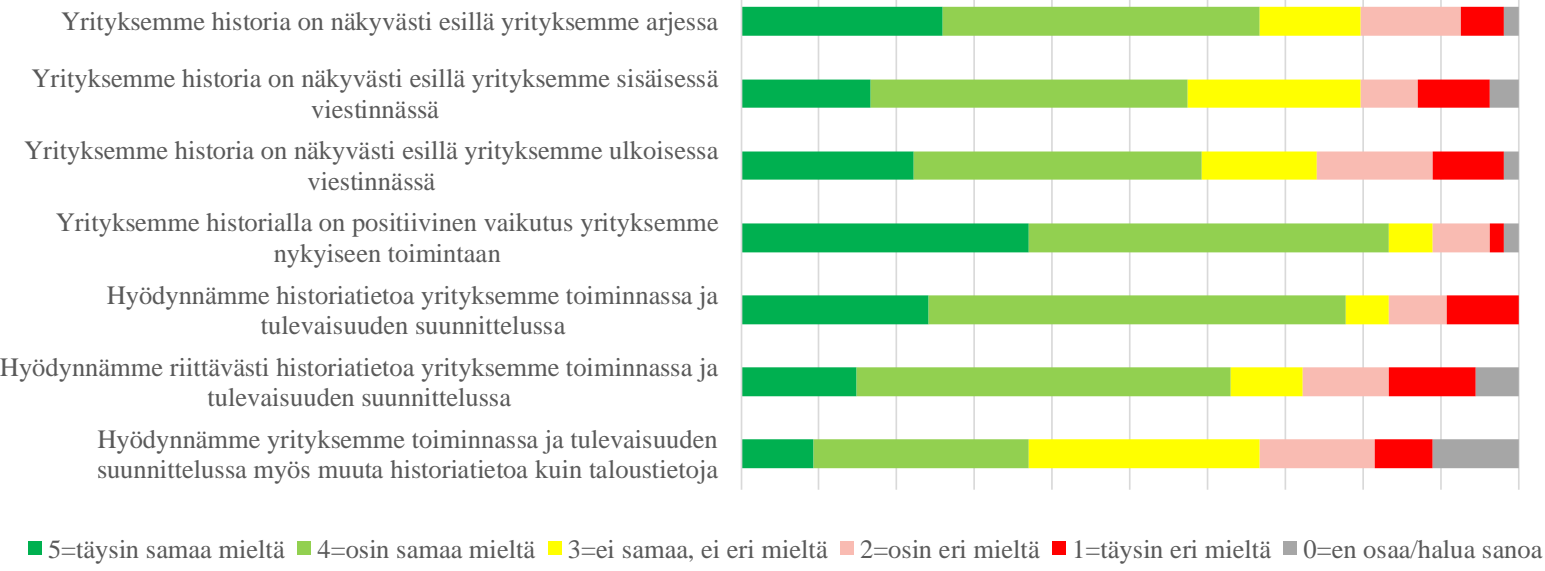

Kuvio 8 Kuinka samaa tai eri mieltä olet seuraavien väittämien kanssa? (\% vastauksista, $\mathrm{N}=54$ ) 
Kuinka yritykset sitten konkreettisesti hyödyntävät historiaa arjessaan? Tätä selvitettiin Kuvion 9 kysymyspatteristolla. Kun aiemmissa vastauksissa korostui yrityksen sisäinen kehittäminen historiatiedon avulla, niin Kuviossa 9 korostuu historiakuva (Kuvio 1): se, miltä yritys näyttää ulospäin. Erityisen keskeisenä nähtiin yrityksen tarinan kertominen historian avulla. Tarinnallisuus ja "jaetut narratiivit" on nostettu keskeisiksi yritysten historiatietoisuuden selittäjiksi myös kansainvälisessä tutkimuksessa. Tänä päivänä (historiallisen) tarinallisuuden leviäminen ja aktiivinen levittäminen on aiempaa helpompaa sosiaalisen median välityksellä, millä on nähty olevan myös laajempia taloudellisia vaikutuksia (Shiller, 2017). Aihetta on tutkittu myös liiketoimintahistorian näkökulmasta (Foster et al., 2017; Mordhorst \& Schwartzkopf, 2017; Labaki \& al., 2019).

Taulukon 3 perusteella yrityksen ikä vaikuttaa yritysten historian käyttöön: yhtäältä kaikkein nuorimmat ja toisaalta kaikkein iäkkäimmät yritykset käyttävät historiaa aktiivisesti, sen sijaan "keski-ikäiset" (26-50-vuotiaat yritykset) selvästi vähemmän. Ei ole yllätys, että eniten historiaa hyödyntävät kaikkein vanhimmat yritykset (51 vuotta tai vanhemmat). Vanhimmille yrityksille historian käyttö on erityisen tärkeää yrityksen tarinan kertomisessa, mutta toiseksi tärkeintä yrityksen strategisessa johtamisessa. Yrityksen koolla ei aineiston perusteella ole juurikaan vaikutusta historian käyttöön. Sen sijaan yrityksen markkina-alueella on suuri merkitys historian käyttöön: paikallisilla tai alueellisilla markkinoilla toimiville yrityksille historian käyttö ei ole niin merkittävää kuin kansallisilla, kansainvälisillä tai globaaleilla markkinoilla toimiville yrityksille.

Taulukko 3 Historian käyttö erityyppisillä yrityksillä

(Keskiarvot vastauksista 1=ei lainkaan, 5 erittäin paljon)

\begin{tabular}{lllllll}
\hline & Markkinointi & Tarina & Brändäys & Viestintä & Strategia & N \\
\hline Kaikki & 3,0 & 3,5 & 3,1 & 2,9 & 2,8 & 54 \\
Ikä 25 v tai nuorempi & 3,0 & 3,3 & 2,9 & 2,8 & 2,8 & 24 \\
Ikä 26-50 v & 2,5 & 3,3 & 2,9 & 2,5 & 2,5 & 15 \\
Ikä 51 v tai vanhempi & 3,3 & 3,9 & 3,4 & 3,4 & 3,6 & 7 \\
Liikevaihto alle 5 me & 3,2 & 3,6 & 3,1 & 2,9 & 2,9 & 31 \\
Liikevaihto 5 me tai enemmän & 3,0 & 3,6 & 3,2 & 3,1 & 3,0 & 21 \\
Paikallinen tai alueellinen markkina & 2,9 & 3,3 & 2,8 & 2,4 & 2,6 & 17 \\
Kansallinen markkina & 2,9 & 3,5 & 3,0 & 3,0 & 3,0 & 17 \\
Kansainvälinen tai globaali markkina & 3,2 & 3,6 & 3,4 & 3,2 & 2,9 & 20 \\
\hline
\end{tabular}

Historian käyttö siis korostuu yrityksen tarinan kertomisessa, markkinoinnissa ja brändäyksessä. Sen sijaan hieman vähemmän historiaa hyödynnetään strategisessa johtamisessa tai henkilöstöjohtamisessa. Avovastauksissa vastaajat nostivat esimerkkeinä historian käytöstä muun muassa yrityskulttuurin rakentamisen, henkilöstön sitouttami- 
sen sekä erilaiset historiaa hyödyntävät artefaktit kuten liiketilojen sisustus ja liikelahjat. Yksi vastaaja myös totesi, että yritys hyödyntää historiaa "jokapäiväisessä asiakaskohtaamisessa".

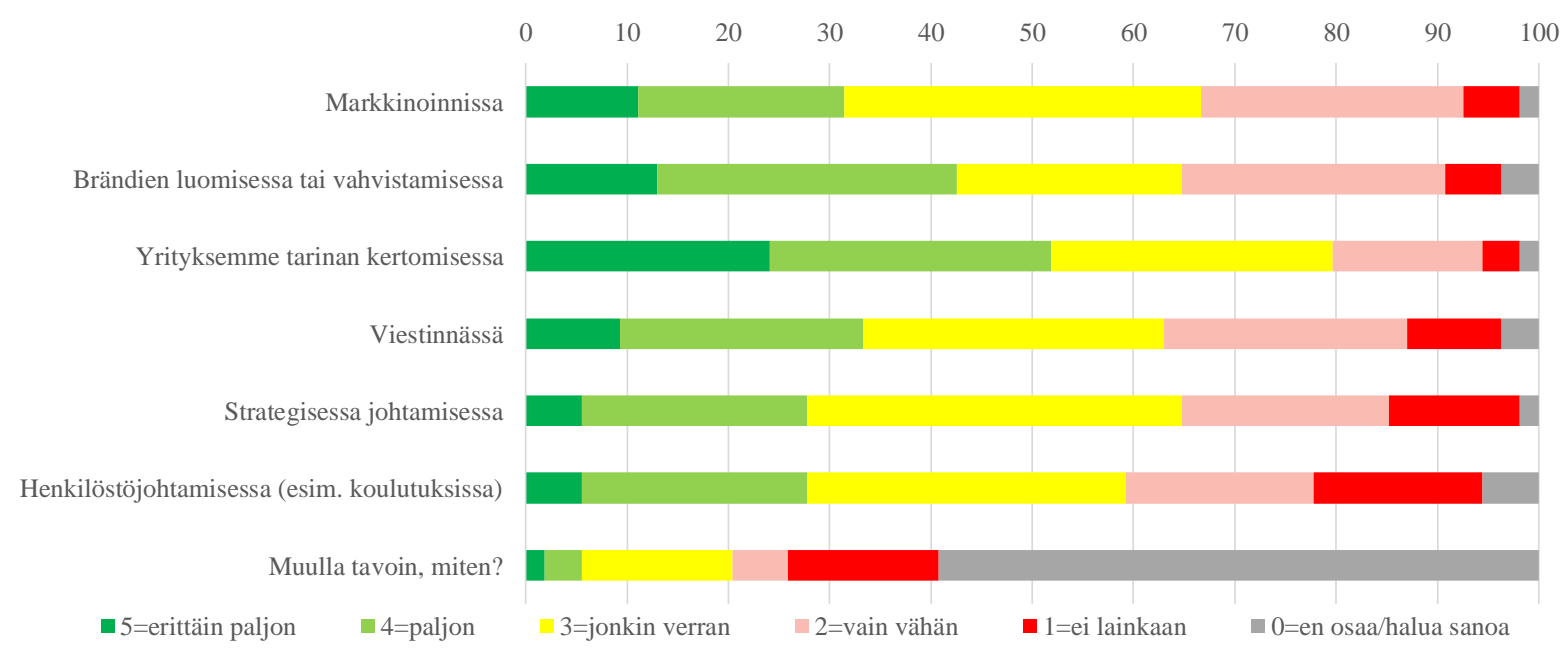

Kuvio 9 Hyödynnämme yrityksemme historiaa... (\% vastauksista, $\mathrm{N}=54$ )

Mitä sitten historiasta tarkalleen ottaen hyödynnetään? Tätä pyrimme selvittämään Kuvion 10 kysymyksillä. Kysymyspatteriston valmiit vastaukset koettiin ilmeisen vieraina, silla vain harva vastaaja koki väittämien historiaelementtien käyttämisen tärkeäksi tai erittäin tärkeäksi. Osa jätti myös kokonaan vastaamatta tähän kysymykseen. Hieman yllättäen esimerkiksi yritysten kotipaikan historiaa hyödynsi paljon tai erittäin paljon vain noin 15 prosenttia vastaajista, vaikka paikallisuus korostui kyselyn muissa osioissa. Oman toimialan hyödyntäminen korostui tässä: reilusti yli puolet koki hyödyntävänsä sitä jonkin verran ja runsas viidennes paljon tai erittäin paljon. Avovastauksissa tarkennettiin hyödynnettävänä historiatietoina muun muassa suvun, yrityksen ja asiakkaiden historia sekä Euroopan talousalueen historia. Myös tekniikan ja teollisuuden historia nähtiin hyödynnettävänä resurssina. 


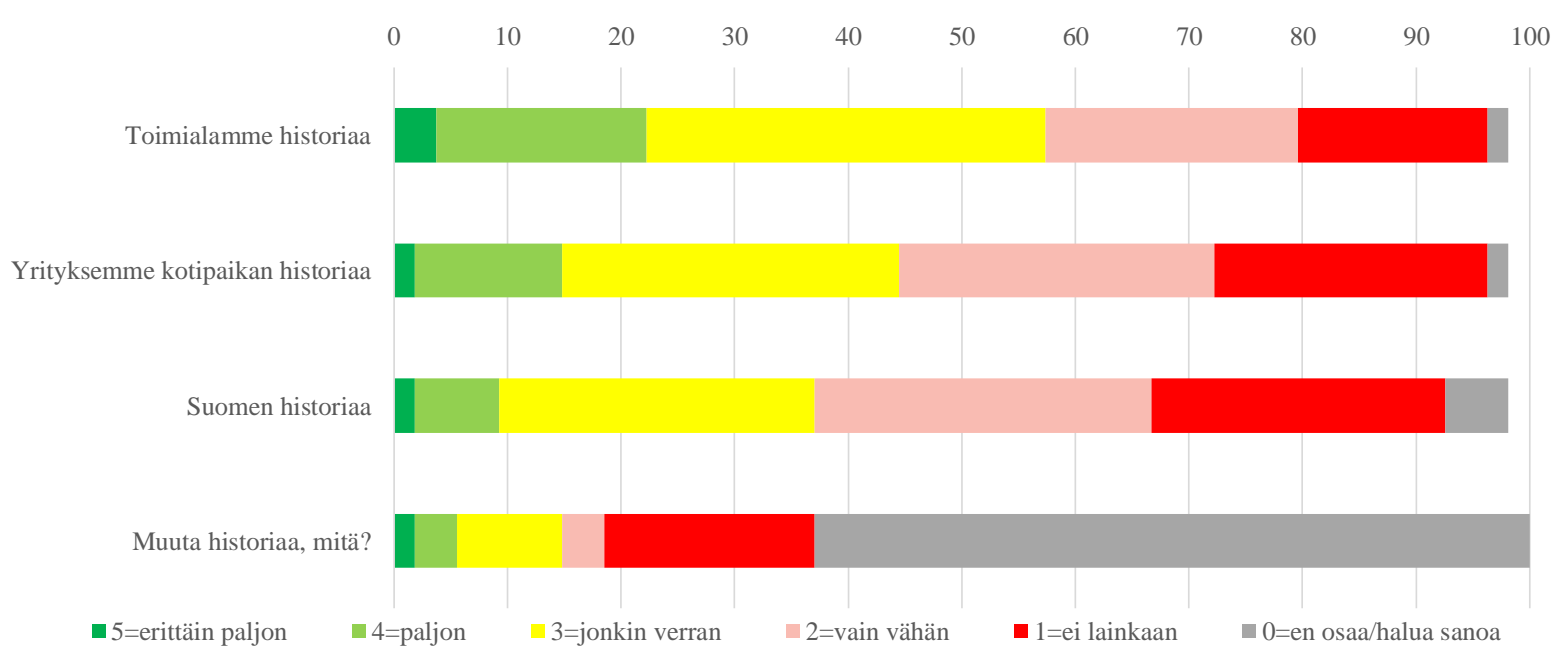

Kuvio 10 Yrityksemme toiminnassa hyödynnetään... (\% vastauksista, N=54)

Tulevaisuudessa nähtiin sen sijaan paljon potentiaalia historian hyödyntämiseen. Moniulotteisella kysymyksellä (Kuvio 11) yhdistimme Kuvioiden 9 ja 10 sisällöt tulevaisuuden pohdinnan tueksi, esimerkiksi kysymällä onko yritys suunnitellut hyödyntävänsä yrityksen omaa tai toimialan historiaa tulevaisuudessa. Vastaukset on koottu Kuvioon 11, jonka perusteella eniten potentiaalia nähdään oman yrityksen historian hyödyntämisessä ja siinä puolestaan yrityksen tarinan kertomisessa. Peräti 80 prosenttia vastaajista näki tarinallisuudessa olevan potentiaalia tulevaisuudessa. Myös markkinoinnissa ja brändäyksessä oman yrityksen historiaa hyödyntämisessä nähtiin potentiaalia, kuten myös yleisemmin viestinnässä. Sen sijaan selvästi harvempi yritys näki oman yrityksen historialle hyödynnettävää käyttöä strategisessa johtamisessa tai henkilöstöjohtamisessa. Myös tämän kysymyksen avovastauksissa tulevaisuuden potentiaalia nähtiin muun muassa asiakkaiden historian hyödyntämisessä sekä tarinnallisuuden yhdistämisessä osaksi myyntiä.

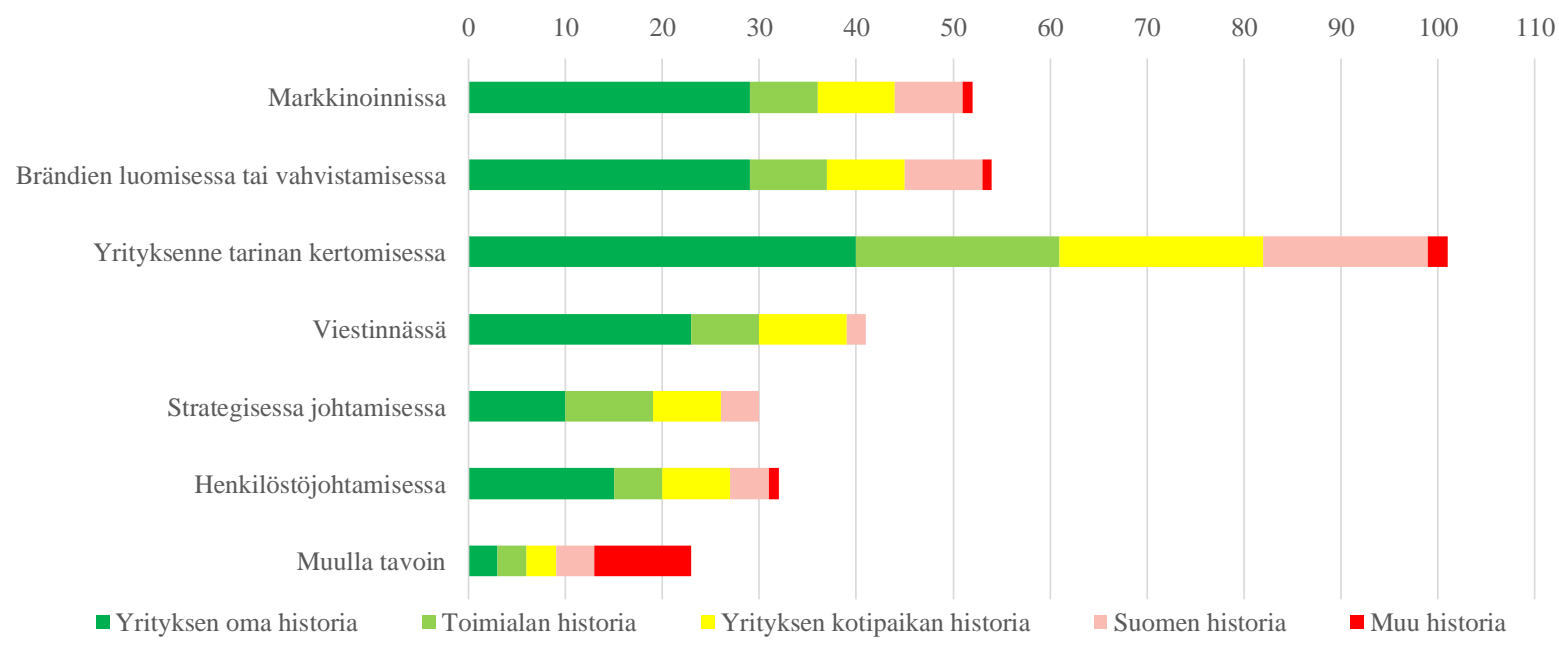

Kuvio 11 Suunnitteletteko hyödyntävänne historiaa tulevaisuudessa... (vastausten lukumäärä) 


\section{JOHTOPÄÄTÖKSET}

Tässä raportissa kuvattiin keskisuomalaisyritykselle tehdyn kyselyn päätulokset, joiden perusteella alueen yritykset ovat kiinnostuneita historiasta ja ovat halukkaita hyödyntämään historiaa tulevaisuudessa etenkin markkinoinnissa ja yrityksen tarinan kertomisessa. Vaikka vastaajien määrä jäi suppeahkoksi ja nettikyselyyn liittyy vastausten vinoutumisen ongelmia, ovat tulokset linjassa historiatietoisuutta pohtivan kansainvälisen ja kotimaisen teoreettisen kirjallisuuden kanssa. Tätä keskustelua on käyty etenkin historian didaktiikan, liiketoimintahistorian ja organisaatiotutkimuksen piirissä.

Seuraavassa vaiheessa kyselyn tuloksia hyödynnetään, kun tutkimusryhmä rakentaa kyselyn, joka suunnataan kaikille suomalaisyritykselle. Samalla on syytä pohtia mahdollisia lisämuuttujia (kuten yhteiskuntasuhteet) ja vastaavasti joidenkin yksityiskohtaisempien muuttujien jättämistä pois kyselystä. Mahdollisesti laajempaan kyselyyn voisi lisätä avokysymyksiä, joilla vastaajat voisivat vapaammin reflektoida yrityksensä tapoja hyödyntää historiaa. 


\section{LIITTEET}

\section{Liite 1 Vastanneiden yritysten ja vastaajien profiili}
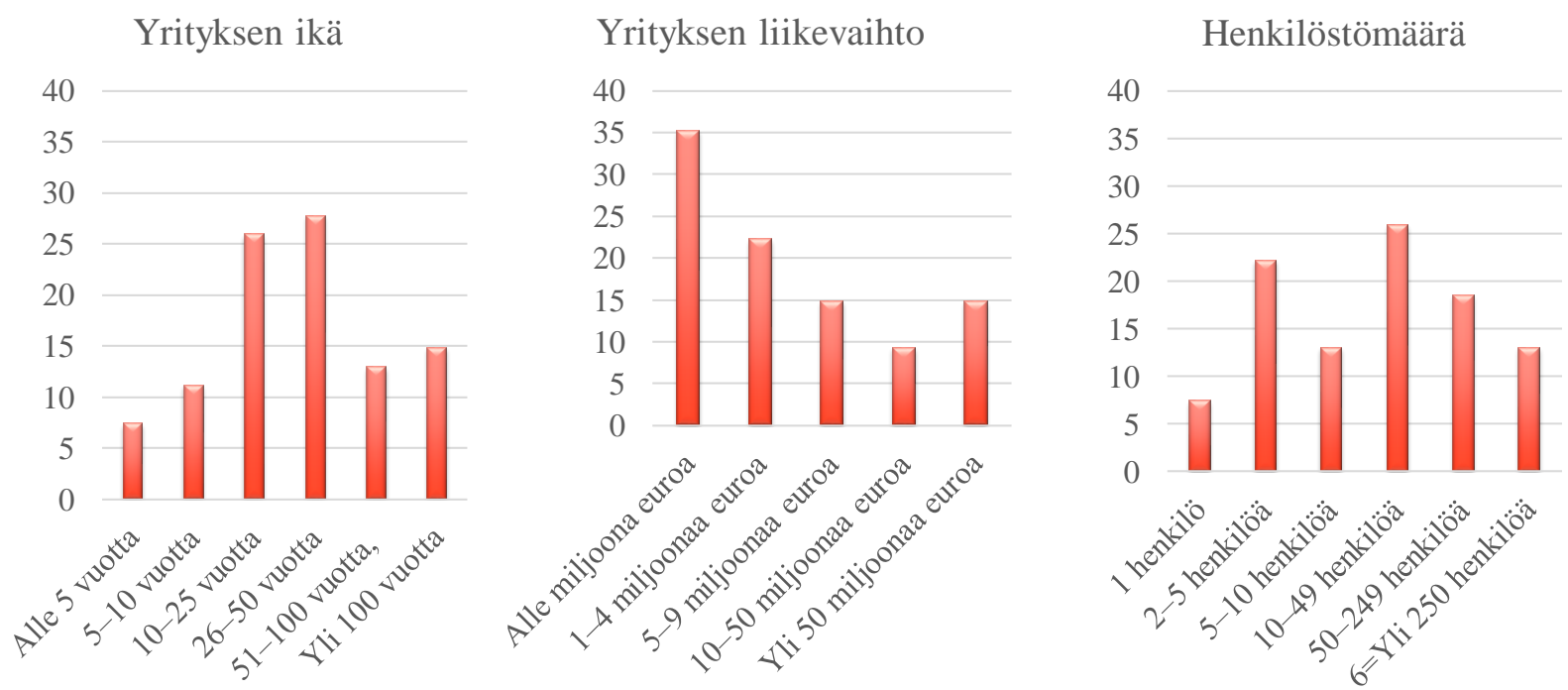

Liitekuviot 1-3 Kyselyyn vastanneet yritykset (\% vastanneista, $N=54$ )
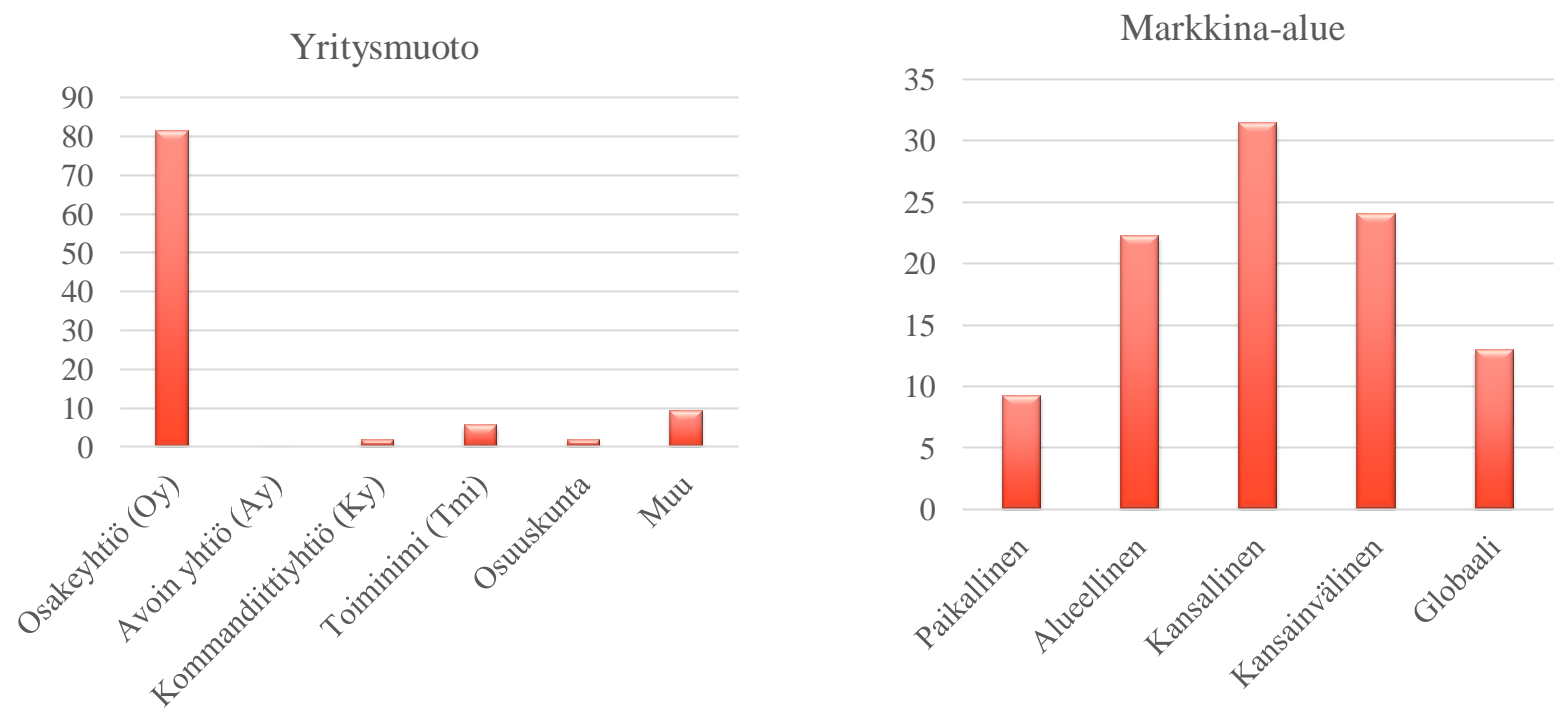

Liitekuviot 4-5 Kyselyyn vastanneet yritykset (\% vastanneista, $\mathrm{N}=54$ ) 


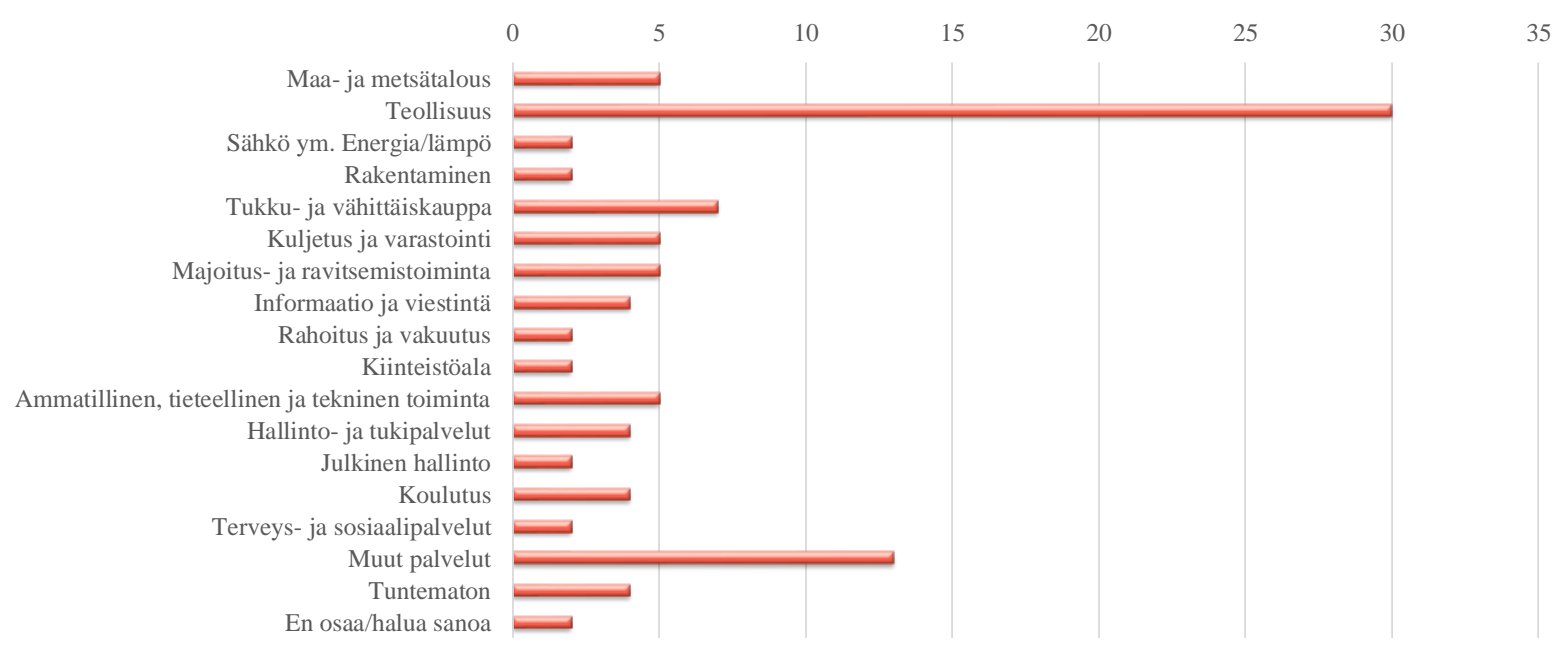

Liitekuvio 6 Kyselyyn vastanneiden yritysten toimiala (\% vastanneista, N=54)

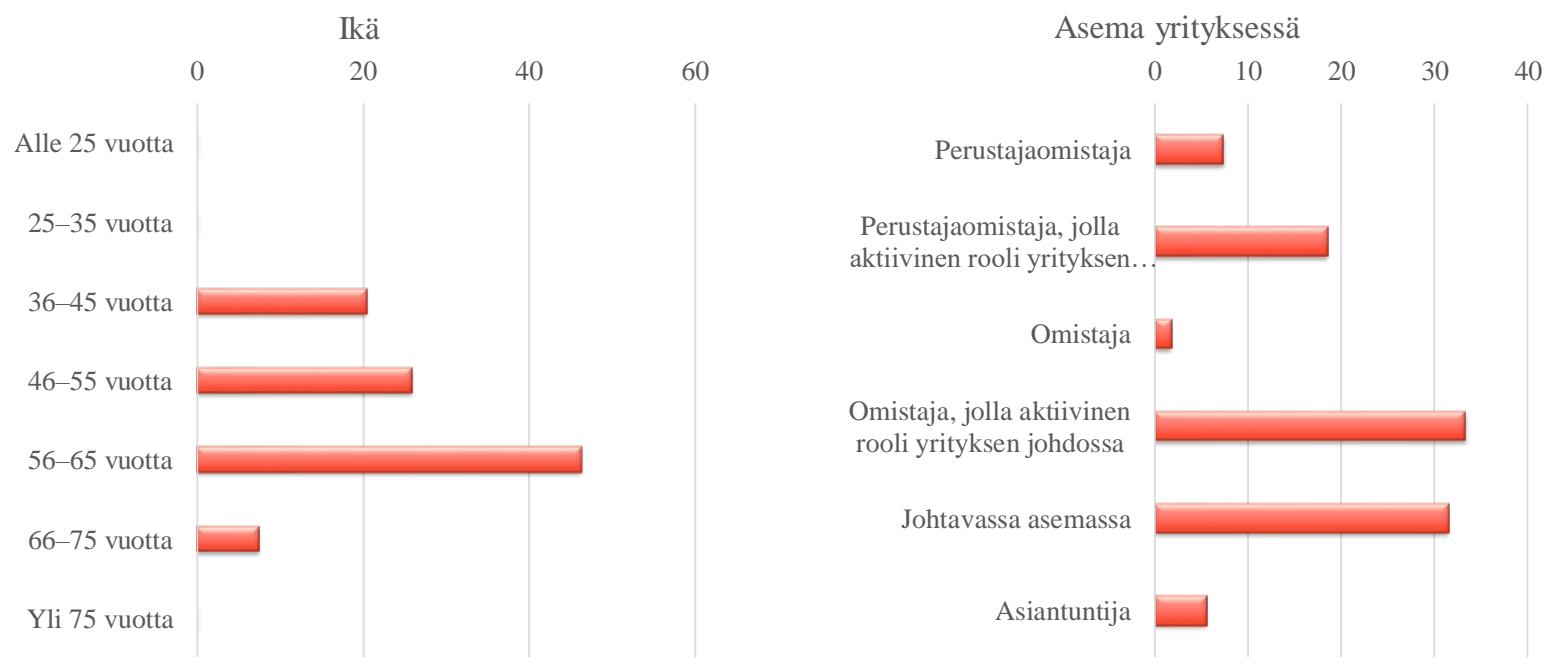

Liitekuviot 7-8 Vastaajien profiili (\% vastanneista, $\mathrm{N}=54$ ) 


\section{Liite 2 Kyselylomake}

1. Mitä historia merkitsee sinulle henkilökohtaisesti?

(Vaihtoehdot: Täysin samaa mieltä, Osin samaa mieltä, Ei samaa eikä eri mieltä, Täysin eri mieltä, En osaa/halua sanoa)

Kiehtovia asioita, jotka kiinnostavat minua

Tilaisuutta oppia muiden virheistä ja onnistumisista

Menneitä ja kuolleita asioita, jotka eivät kosketa tai kiinnosta minua

Taustaa nykytilanteelle ja selityksiä nykyongelmille

Tietoa, joka auttaa minua ymmärtämään yhteiskuntaa ja sen kehitystä

Tietoa, joka auttaa minua ymmärtämään talouden kehityskulkuja ja ilmiöitä

Yleissivistystä: perustiedot historiasta kuuluvat jokaisen yleissivistykseen

Oppiainetta koulussa, johon liittyviä tietoja tai taitoja en ole tarvinnut kouluaikojeni jälkeen

2. Kuinka kiinnostavana pidät seuraavia asioita?

(Vaihtoehdot: Erittäin kiinnostava, Kiinnostava, Jonkin verran kiinnostava, Vain vähän kiinnostava, Ei lainkaan kiinnostava, En osaa/halua sanoa)

Historia ja menneisyys yleensä

Taloushistoria

Ihmisten arkeen liittyvä historia

Oman perheeni ja sukuni historia

Oman asuinpaikkani historia

Oman yritykseni historia

Muiden yritysten historia

Yrityksesi toimialan historia

Suomen historia

Euroopan historia

Maailmanhistoria

Muu historia-aihe, mikä? 


\section{Kuinka usein olet?}

(Vaihtoehdot: Viikoittain tai useammin, Kerran/pari kuukaudessa, Kerran/pari vuodessa, Harvemmin kuin kerran vuodessa, En koskaan, En osaa/halua sanoa)

Katsellut, kuunnellut tai lukenut historiaan liittyviä dramatisoituja tai fiktiivisiä teoksia, kuten elokuvia, televisiosarjoja, teatteriesityksiä, romaaneja

Katsellut, kuunnellut tai lukenut historiaan liittyviä tietopohjaisia teoksia, kuten dokumentaarisia ohjelmia, elokuvia tai muita esityksiä, tietokirja tai elämäkertoja

Käynyt historiaa käsittelevillä luennoilla tai esitelmätilaisuudessa

Etsinyt historiaan liittyvää tietoa, esimerkiksi internetistä

Perehtynyt yrityksenne historiaan

Tutustunut muiden yritysten historiaan

Perehtynyt yrityksenne toimialan historiaan

Perehtynyt suvun ja perheen historiaan

Vieraillut historiallisella paikalla tai museossa

Hankkinut keräilymielessä tai muistoksi vanhoja esineitä tai tavaroita

Harrastanut historia-aiheisia rooli-, tietokone- tai lautapelejä

4. Onko yrityksessänne tallennettu tai säilytättekö yrityksenne historiaan liittyviä?

(Vaihtoehdot: Erittäin paljon, Paljon, Jonkin verran, Vain vähän, Ei lainkaan,

En osaa/halua sanoa)

Asiakirjoja/arkistoja

Yrityksen omaa viestintämateriaalia

Lehtiartikkeleita

Kertomuksia tai muisteluita yrityksenne toiminnasta (esim. omistajat, johtajat, työntekijät ja asiakkaat)

Valokuvia, videoita tai muita taideteoksia

Rakennuksia tai tuotantotiloja

Yrityksenne tuotteita

Koneita tai laitteita

Muuta materiaalia, mitä?

5. Onko yrityksestänne kirjoitettu yrityshistoria?

(Vaihtoehdot: On, Ei) 
6. Kuinka kiinnostuneita olisitte...

(Vaihtoehdot: Erittäin kiinnostunut, Kiinnostunut, Jonkin verran kiinnostunut, Vain vähän kiinnostunut, Ei lainkaan kiinnostunut, En osaa/halua sanoa)

yritykseenne liittyvien asiakirjojen tai dokumenttien arkistoinnista (esim. Elinkeinoelämän keskusarkistoon) tulevaisuudessa?

yritykseen liittyvän muistitiedon tallentamisesta (haastattelut) tulevaisuudessa?

yritykseenne liittyvän esineistön (kuvat, taideteokset, koneet, tuotteet, laitteet, yms.) tallentamisesta tulevaisuudessa?

yritykseenne historiaan liittyvien rakennusten kunnossapidosta tai museoinnista tulevaisuudessa?

siitä, että yrityksestänne kirjoitettaisiin yrityshistoria?

7. Kuinka tärkeä rooli seuraavilla on yrityksenne jokapäiväisessä toiminnassa ja tulevaisuuden suunnittelussa?

Oma henkilökohtainen historiani ja sen vaiheet

Yrityksemme historia ja sen vaiheet

Yrityksemme keskeisten sidosryhmien (esim. henkilöstö, asiakkaat, yhteistyökumppanit tai perheyrityksissä suku) historia ja niiden vaiheet

Yritystämme ympäröivän yhteisön (esim. kylä/kunta/kaupunki) historia ja sen vaiheet Yritystämme ympäröivän yhteiskunnan historia ja se vaiheet

\section{Kuinka samaa tai eri mieltä olet seuraavien väittämien kanssa?}

(Vaihtoehdot: Täysin samaa mieltä, Osin samaa mieltä, Ei samaa eikä eri mieltä, Osin eri mieltä, Täysin eri mieltä, En osaa/halua sanoa)

Yrityksemme historia on näkyvästi esillä yrityksemme arjessa

Yrityksemme historia on näkyvästi esillä yrityksemme sisäisessä viestinnässä

Yrityksemme historia on näkyvästi esillä yrityksemme ulkoisessa viestinnässä

Yrityksemme historialla on positiivinen vaikutus yrityksemme nykyiseen toimintaan Hyödynnämme historiatietoa yrityksemme toiminnassa ja tulevaisuuden suunnittelussa

Hyödynnämme riittävästi historiatietoa yrityksemme toiminnassa ja tulevaisuuden suunnittelussa

Hyödynnämme yrityksemme toiminnassa ja tulevaisuuden suunnittelussa merkittävästi myös muuta historiatietoa kuin taloustietoja 
9. Hyödynnämme yrityksemme historiaa...

(Vaihtoehdot: Erittäin paljon, Paljon, Jonkin verran, Vain vähän, Ei lainkaan, En osaa/halua sanoa)

Markkinoinnissa

Brändien luomisessa tai vahvistamisessa

Yrityksemme tarinan kertomisessa

Viestinnässä

Strategisessa johtamisessa

Henkilöstöjohtamisessa (esim. koulutuksissa)

Muulla tavoin, miten?

10. Yrityksemme toiminnassa hyödynnetään...

(Vaihtoehdot: Erittäin paljon, Paljon, Jonkin verran, Vain vähän, Ei lainkaan, En osaa/halua sanoa)

Toimialamme historiaa

Yrityksemme kotipaikan historiaa

Suomen historiaa

Muuta historiaa, mitä?

11. Suunnitteletteko hyödyntävänne tulevaisuudessa...

(Vaihtoehdot: Yrityksen oma historia, Toimialan historia, Yrityksen kotipaikan historia, Suomen historia, Muu historia)

Markkinoinnissa

Brändien luomisessa tai vahvistamisessa

Yrityksenne tarinan kertomisessa

Viestinnässä

Strategisessa johtamisessa

Henkilöstöjohtamisessa

Muulla tavoin 


\section{Taustatiedot}

12. Kuinka kauan yrityksenne on toiminut?

Alle 5 vuotta

5-10 vuotta

10-25 vuotta

26-50 vuotta

51-100 vuotta,

Yli 100 vuotta

13. Yrityksenne liikevaihto

Alle miljoona euroa

1-4 miljoonaa euroa

5-9 miljoonaa euroa

10-50 miljoonaa euroa

Yli 50 miljoonaa euroa

14. Yrityksenne koko

1 henkilö

2-5 henkilöä

5-10 henkilöä

10-49 henkilöä

50-249 henkilöä

6=Yli 250 henkilöä

15. Onko yrityksenne yritysmuoto?

Osakeyhtiö (Oy)

Avoin yhtiö (Ay)

Kommandiittiyhtiö (Ky)

Toiminimi (Tmi)

Osuuskunta

Muu

16. Onko yrityksenne perheyritys?

(Vaihtoehdot: Kyllä, Ei, En osaa/halua sanoa) 


\section{Yrityksenne toimiala}

(toimialaluokituksen 2008 pääluokat https://www.stat.fi/fi/luokitukset/toimiala)

A Maatalous, metsätalous ja kalatalous

B Kaivostoiminta ja louhinta

C Teollisuus

D Sähkö-, kaasu- ja lämpöhuolto, jäähdytysliiketoiminta

E Vesihuolto, viemäri- ja jätevesihuolto, jätehuolto ja muu ympäristön puhtaanapito

F Rakentaminen

G Tukku- ja vähittäiskauppa; moottoriajoneuvojen ja moottoripyörien korjaus

$\mathrm{H}$ Kuljetus ja varastointi

I Majoitus- ja ravitsemistoiminta

J Informaatio ja viestintä

K Rahoitus- ja vakuutustoiminta

L Kiinteistöalan toiminta

M Ammatillinen, tieteellinen ja tekninen toiminta

N Hallinto- ja tukipalvelutoiminta

O Julkinen hallinto ja maanpuolustus; pakollinen sosiaalivakuutus

P Koulutus

Q Terveys- ja sosiaalipalvelut

$\mathrm{R}$ Taiteet, viihde ja virkistys

S Muu palvelutoiminta

T Kotitalouksien toiminta työnantajina; kotitalouksien eriyttämätön toiminta tavaroiden ja palvelujen tuottamiseksi omaan käyttöön

U Kansainvälisten organisaatioiden ja toimielinten toiminta

$X$ Toimiala tuntematon

En osaa/halua sanoa

18. Yrityksenne markkina-alue

Paikallinen

Alueellinen

Kansallinen

Kansainvälinen

Globaali

Muu, mikä=

En osaa/halua sanoa 
19. Mistä sait tiedon tästä kyselystä?

Keski-Suomen liitolta

Kauppakamarilta

Yrittäjiltä

Muualta, mistä?

En osaa/halua sanoa

20. Asemasi yrityksessä

Perustajaomistaja

Perustajaomistaja, jolla aktiivinen rooli yrityksen johdossa

Omistaja

Omistaja, jolla aktiivinen rooli yrityksen johdossa

Johtavassa asemassa

Asiantuntija

Työntekijä

Muu, mikä?

En osaa/halua sanoa

21. Ikäsi

Alle 25 vuotta

25-35 vuotta

$36-45$ vuotta

46-55 vuotta

56-65 vuotta

66-75 vuotta

Yli 75 vuotta

En osaa/halua sanoa 


\section{Kirjallisuus}

Ahonen, S. (1998). Historiaton sukupolvi? Historian vastaanotto ja historiallisen identiteetin rakentuminen 1990-luvun nuorison keskuudessa. Helsinki: SHS.

Alberti, F. G., \& J. D. Giusti (2012). Cultural heritage, tourism and regional competitiveness: The Motor Valley cluster. City, culture and society, 3(4), 261273.

Arthur, W. B. (1989). Competing technologies, increasing returns and lock-in by historical events. The Economic Journal, 99, 116-131.

Barney, J. B. (1991). Firm resources and sustained competitive advantage. Journal of Management,17, 99-120.

Berndtson, T. \& J. Lounasmaa (2004). Internet tutkijan työkaluna. Tietoaika, Tilastokeskus

https://www.stat.fi/tup/tietoaika/tilaajat/ta_06_04_internet_tyokalu.html. Viitattu 3.5.2021.

Berg van den, M. (2007). Yksi historia monimutkaistuvassa maailmassa - historian olemus ja historian suuret kertomukset luokanopettajaopiskelijoiden historiatietoisuudessa. Historiallisyhteiskunnallistiedollisen kasvatuksen tutkimus- ja kehittämiskeskus, Helsinki.

Blombäck, A., \& O. Brunninge (2016). Identifying the role of heritage communication: A stakeholder-function framework. International Studies of Management \& Organization, 46(4), 256-268.

Brunninge, O. (2009). Using history in organizations: How managers make purposeful reference to history in strategy processes. Journal of Organizational Change Management, 22(1), 8-26.

Clark, P. \& M. Rowlinson (2004). The treatment of history in organisation studies: Towards an 'historic turn'? Business History, 46(3), 331-352.

David, P. A. (1985). Clio and the economics of QWERTY. American Economic Review, 75(2), 332-337.

Foster, W. M. et al. (2017). The strategic use of historical narratives: a theoretical framework. Business History, 59(8), 1176-1200.

Foster, W. M. et al. (2011). History as social memory assets: The example of Tim Hortons. Management and Organizational History, 6(1), 101-120.

Gadamer, H. G. \& H. Fantel (1975). The problem of historical consciousness. Graduate Faculty Philosophy Journal, 5(1), 8-52.

Hiljanen, M., J. Ojala, M. Rautiainen, J. Seppälä \& P. Vuorenpää (2021). Historical Consciousness among Family Firms. A new approach to understand the uses of the past. (käsikirjoitus) 
Kieser, A. (1994). Why organization theory needs historical analyses-and how this should be performed. Organization Science, 5(4), 608-620.

Labaki, R., F. Bernhard \& L. Cailluet (2019). The strategic use of historical narratives in the family business. The Palgrave handbook of heterogeneity among family firms (pp. 531-553).

Maclean, M., C. Harvey, J. A. Sillince \& B. D. Golant (2018). Intertextuality, rhetorical history and the uses of the past in organizational transition. Organization Studies, 39(12), 1733-1755.

Mills, A. J., R. Suddaby, W. M. Foster \& G. Durepos (2016). Re-visiting the historic turn 10 years later: Current debates in management and organizational history an introduction. Management \& Organizational History, 11(2), 67-76.

Mokyr, J. (2016). A culture of growth. Princeton University Press.

Mordhorst, M. \& S. Schwarzkopf (2017). Theorising narrative in business history. Business History, 59(8), 1155-1175.

Pihlainen, K. (2011). Historia, historiatieto ja menneisyyden käyttö. Kasvatus \& Aika 5(3), 5-17.

Rindell, A., F. P. Santos \& A. P. de Lima (2015). Two sides of a coin: Connecting corporate brand heritage to consumers' corporate image heritage. Journal of Brand Management, 22(5), 467-484.

Rosenzweig, R. \& D. Thelen (1998). Presence of the Past. Popular Uses of History in American Life. New York: Columbia University Press.

Rüsen, J. (2004). Historical Consciousness: Narrative Structure, Moral Function, and Ontogenetic Development. In: Peter Seixas (ed.) (2004). Theorizing Historical Consciousness. Toronto: University of Toronto Press, 63-85.

Shiller, R. J. (2017). Narrative economics. American Economic Review, 107(4), 9671004.

Seixas, P. \& C. Peck, (2004). Teaching Historical Thinking. In A. Sears \& I. Wright (Eds.). Challenges and Prospects for Canadian Social Studies. Vancouver: Pacific Educational Press.

Seixas, P. (ed.) (2004). Theorizing Historical Consciousness. Toronto: University of Toronto Press

Seixas, P. (2004). Introduction. In: Peter Seixas (ed.) (2004). Theorizing Historical Consciousness. Toronto: University of Toronto Press, 3-20.

Suddaby, R., \& W. M. Foster (2017). History and Organizational Change. Journal of Management, 43(1), 19-38.

Suddaby, R., W. M. Foster \& C. Quinn-Trank (2010). Rhetorical History as Competitive Advantage. Advances in Strategic Management, 27, 147-173. 
Teece, D. J., G. Pisano \& A. Shuen, (1997). Dynamic capabilities and strategic management. Strategic Management Journal, 18(7), 509-533.

Torsti, P. (2011). Suomalaisten moniulotteiset sotakuvat. Historiallinen aikakauskirja 3/2011, 309-323.

Torsti, P. (2012). Suomalaiset ja historia. Helsinki: Gaudeamus.

Torsti, P., K. Knuuttila \& A. Hämäläinen (2012). Historiatietoisuus Suomessa -tutkimushankkeen analyysikäsikirja. https://www.gaudeamus.fi/wpcontent/uploads/2012/09/Historiatietoisuus_Suomessa_analyysikasikirja_Verkk oon.pdf

Torsti, P. \& J. Aunesluoma (2009). Historian käyttö yhteiskunnassa ja tutkimuksessa. Historiallinen aikakauskirja 3/2009, 276-279.

Torsti, P. \& H. Wass (2011). Limittyvät sukupolvet ja jaetut näkemykset. Suomalaiset yhteiskunnalliset sukupolvet ja sukupolvittaiset erot poliittisessa käyttäytymisessä. Politiikka 3/2011.

Vaara, E., \& J. A. Lamberg (2016). Taking historical embeddedness seriously: Three historical approaches to advance strategy process and practice research. Academy of Management Review, 41(4), 633-657.

Veijola, A. \& S. Mikkonen (2016). Mitä historia on: aloittavien historianopiskelijoiden historiakäsitykset. Kasvatus ja Aika 10(3), 6-21.

Veijola, A. (2016). Historiatietoisuus, historiallinen ajattelu ja historian tekstitaidot: Uuden opetussuunnitelman moninaiset lähtökohdat. Kasvatus ja Aika 10(2), 618.

Üsdiken, B. \& A.Kieser (2004). Introduction: History in organisation studies. Business History, 46(3), 321-330. 


\section{Kirjoittajat}

Jari Ojala on liiketoimintahistorian professori Jyväskylän yliopistossa ja Menestystä menneisyydestä -tutkimushankkeen vastuullinen johtaja.

FT Mikko Hiljanen on yliopistonopettaja Jyväskylän yliopiston opettajankoulutuslaitoksella.

KTM Anu Ojala on strategian ja yrittäjyyden väitöskirjatutkija Jyväskylän yliopiston kauppakorkeakoulussa.

FT Jarmo Seppälä on tutkijatohtori strategian ja yrittäjyyden oppiaineessa Jyväskylän yliopiston kauppakorkeakoulussa.

KT Matti Rautiainen on vanhempi yliopistonlehtori Jyväskylän yliopiston opettajankoulutuslaitoksella.

FM Pirjo Vuorenpää on taloushistorian väitöskirjatutkija Jyväskylän yliopiston historian ja etnologian laitoksella. 